\title{
Şehir ve Bölge Planlama Disiplininde Eğitim, İş Bulma ve Mesleki Öz Yeterliliğe ilişkin Kaygı ve Beklentiler
}

\author{
Seher ÖZKAZANÇ ${ }^{1 *}$, Cansu KORKMAZ \\ ORCID 1: 0000-0001-7618-2494 \\ ORCID 2: 0000-0003-4570-1751 \\ ${ }^{1}$ Necmettin Erbakan Üniversitesi, Mühendislik ve Mimarlık Fakültesi, Şehir ve Bölge Planlama Bölümü, 42030, \\ Konya, Türkiye. \\ ${ }^{2}$ Konya Teknik Üniversitesi, Mimarlık ve Tasarım Fakültesi, Şehir ve Bölge Planlama Bölümü, 42130, Konya, Türkiye. \\ *e-mail: seherpolat7@gmail.com
}

Öz

Türkiye'nin savaş sonrası kalkınma hamleleri, yatırımların bölgeler arası farklılaşması, kırdan kente gö̧ hareketleri, konut taleplerinin hızla artması vb. gelişmeler sonucunda kentlerin kontrolsüz büyümeye başlaması planlı bir kentleşmeyi zorunlu kılmakla birlikte ülkede şehir plancısı ihtiyacını da gündeme taşımıştır. Bu ihtiyacın karşılanabilmesi için dünyada yirminci yüzyılda başlayan planlama eğitimi ülkemizde yarım asrı aşkın bir süre sonra Orta Doğu Teknik Üniversitesi'nde (ODTÜ) Şehir ve Bölge Planlama Bölümü’nün açılmasıyla başlamıştır. Lisans düzeyinde eğitim veren bölümler Izmir ve Istanbul başta olmak üzere diğer kentlerde de yaygınlaşmış, bölüm sayısı özellikle son on yılda ivmelenerek 2018 yılı itibariyle 27’ye ulaşmıştır. Günümüzde kentsel sorunların yaygınlaşması plancıların görev kapsamını genişleterek mesleki açıdan daha donanımlı olmalarını zorunlu kılmıştır. Nitekim şehir plancıları; geleneksel planlama tekniklerinin yanı sıra teknolojik gelişmelere de ayak uydurabilen, parçacıl bakış açısı yerine ilişkisel bütünlüğü sentezleyebilen, sürdürülebilir ve yaşanabilir bir kent için karmaşık kentsel sistemlerin işleyişini yorumlayabilecek teorik, pratik ve teknik bilgi düzeyine sahip olmalıdır. Ancak şehir planlama yaklaşımlarında yaşanan bu devinim, bölüm sayısının hızla artmasıyla birlikte mezunlar arasında daha rekabetçi bir ortamı da beraberinde getirmiştir. Mesleki yeterliliğin ve rekabetin önem kazanması ise hem lisans öğrencileri hem de mezunlarda mesleki bir baskıya, kaygıya sebep olurken planlama eğitiminin çağın koşullarına adaptasyonunu bir kez daha sorgulatmaktadır. Bu bağlamda Türkiye'de Şehir ve Bölge Planlama eğitimi veren bölümlerin öğrenci ve profesyonel plancı (kamu ve özel sektörde çalışan şehir plancıları ile akademisyenler) bakış açısıyla değerlendirilmesi; plancı adaylarını bekleyen iş bulmaya ve mesleki hayata yönelik problemlerin ortaya konulması çalışmanın temel amacını oluşturmaktadır.

Anahtar Kelimeler: Şehir ve bölge planlama eğitimi, şehir plancısı, işsizlik kaygısı, mesleki öz yeterlilik.

Atıf: Özkazanç, S., Korkmaz, C. (2019). Şehir ve Bölge Planlama Disiplininde Eğitim, İş Bulma ve Mesleki Öz Yeterliliğe İlişkin Kaygı ve Beklentiler. Mimarlık Bilimleri ve Uygulamaları Dergisi (MBUD), 4 (2), 122-139.

DOI: $\underline{10.30785 / \mathrm{mbud} .582936}$ 


\title{
Anxiety and Expectations Related to Education, Employment and Professional Self-Efficacy in City and Regional Planning Discipline
}

\begin{abstract}
Uncontrolled growth of cities in Turkey as a result of the developments such as post-war development moves, differentiation of investments between regions, migration movements from rural to urban and rapidly increasing housing demand have necessitated not only a planned urbanization, but also brought forward the need for urban planners in the country. In order to meet this need, planning education starting in the world in the twentieth century has begun in our country with the opening of the Department of City and Regional Planning in Middle East Technical University (METU) after more than half a century. Departments providing undergraduate education have also become widespread in other cities, particularly in Izmir and Istanbul, and the number of departments has increased especially in the last decade and reached 27 by 2018. Nowadays, the prevalence of urban problems has made it necessary for planners to become professionally more equipped by expanding their scope of work. In this regard, urban planners should have theoretical, practical and technical knowledge level that can adapt to technological developments as well as traditional planning techniques, synthesize relational integrity instead of fragmentary perspective, and interpret the process of complex urban systems for a sustainable and livable city. However, this movement lived in urban planning approaches has brought along a more competitive environment among graduates with a rapid increase in the number of departments. The increasing importance of professional competence and competition causes professional pressure and anxiety both for undergraduate students and graduates, and once again make us question the adaptation of planning education to the conditions of the age. In this manner, the main purposes of this study are to evaluate the departments providing education on City and Regional Planning in Turkey from the perspective of students and professional planners (city planners and academics working in the public and private sectors) and to put forward the problems waiting for the planner candidates related to finding jobs and professional life.
\end{abstract}

Keywords: City and regional planning education, urban planner, unemployment anxiety, professional selfefficacy.

\section{Giriş}

Kentin planlanması ve düzenlenmesi fikri çok eski çağlara dayanmakla birlikte, şehir planlama eğitimi ilk kez civic design adı altında Liverpool Üniversitesi'nde başlamış, daha sonra 1913 yılında Lviv Teknik Üniversitesi (Ukrayna), 1914 yılında University College London (İngiltere), 1915 yılında Karlsruhe Teknoloji Enstitüsü (Almanya) kent planlamayı öğretim programlarına dâhil etmiştir (TUPOB, 2007). Dönemin planlamaya yön veren gelişmesi Robert E. Park, Ernest Burgess, Mc Kenzie, Louis Wirth ve Everett Hughes gibi sosyologların öncülüğünde kurulan Chicago School of Sociology olmuş, böylece planlamanın toplumsal boyutuna vurgu yapılmıştır (Doğan ve Ocakçı, 2014). Şehir planlamanın bağımsız bir eğitim alanı olarak gelişmesi ve 1923 yılında Harvard Üniversitesi'nde planlama okullarının kurulmasıyla birlikte planlama eğitimi başta Amerika olmak üzere Avrupa'da da (Massachusetts Teknoloji Enstitüsü, Cornell, Columbia ve Illinois Üniversiteleri) yaygınlaşmaya başlamıştır (Hall, 1996). 1938 yılında Amerika Kent Planlama Enstitüsü'nün bölge planlamayı da programına eklemesiyle birlikte planlamanın eğitim alanı genişlemiştir (TUPOB, 2007).

Türkiye'de ise şehir planlama ilk kez 1930'lu yıllarda İstanbul Teknik Üniversitesi ve Mimar Sinan Güzel Sanatlar Akademisi'nde mimarlık eğitiminin bir parçası olarak verilen şehircilik dersleri ile ortaya çıkmıştır. Aynı dönemde Ankara Siyasal Bilgiler Fakültesi'nde Şehircilik Kürsüsü açıımış ancak temel amaç şehir plancısı yetiştirmekten öte mimar adaylarını şehircilik ve planlama alanında bilgilendirmek olmuştur (Keleş vd., 1973). 1950 yılından itibaren kırdan kente göçün hızlanması ve dolayısıyla kentlerde barınma ihtiyacının artması ciddi bir planlama (plansızlık) sorununu da beraberinde getirmiştir. Kentlerin büyümesini kontrol altına alabilmek ve planlı bir gelişmeyi sağlayabilmek için yurtdışından plancı ikamesi aslında ülkedeki eksikliği de açığa çıkarmıştır. Bu sebeple 1961 yılında Orta Doğu Teknik Üniversitesi'nde (ODTÜ) Türkiye'nin ilk Şehir ve Bölge Planlama Bölümü kurularak şehir plancısı ihtiyacı giderilmeye çalışılısıstır (URL-1). ODTÜ Türkiye'de şehircilik eğitiminin yanı sıra kentsel ve bölgesel araştırmaların gelişmesinde de önemli rol oynamıştır (Köroğlu, 2011). 1980'li yılların sonuna kadar Şehir ve Bölge Planlama Bölümlerinin sayısı 6'ya 
yükselirken, 2018 yılı itibariyle 129 devlet üniversitesinin 25'inde, 72 vakıf üniversitesinin 2'sinde planlama eğitiminin aktif olarak yürütüldüğü görülmektedir (URL-2).

Şehir ve Bölge Planlama eğitimi günümüzde mekânsal gelişim ve toplumsal refah, halk katılımı ve uyuşmazlıkların çözümü konularında deneyime sahip plancı yetiştirmeyi hedeflemektedir (Kotval, 2003). Bu deneyim teorik altyapının yanı sıra, büyük oranda problem çözümüne yönelik uygulamalı dersler ile sağlanmaktadır. Probleme dayalı uygulamalı öğrenme üzerine kurgulanan dersler özellikle sağlık bilimleri, insan kaynakları, şehir planlama, kamu yönetimi, mühendislik, bilgi teknolojisi ve hatta ekonomi, coğrafya ve biyoloji alanlarında tartışılmaktadır. Her ne kadar bu derslerin içeriği, program yapısı ve çıktıları bir disiplinden diğerine değişse de temel fayda bakımından benzerlikler bulunmaktadır. İlk olarak, bu derslerde öğrencilerin sorunları daha derinlemesine anladığı, tartışma ve etkileşim olanaklarının bulunduğu ve bir konu hakkında özgün bir fikir edindiği savunulmaktadır (Gibbs, 1992; Higgitt, 1996; Kent vd., 1997). Ayrıca bu dersler akran öğrenimini ilerleten ve işbirlikçi öğrenmenin ilkelerini temel alan küçük grup egzersizlerini geliştirme eğilimindedir (Yabes, 1996). Küçük grup öğretimi ise öğrencilere daha kişisel, daha donanımlı ve zorlu bir eğitim deneyimi sağlama potansiyeline sahiptir (Clark ve Wareham, 1998).

Planlama eğitiminde uygulamaya ağırlık verilmesi planlamanın salt disiplin olmayıp aynı zamanda bir meslek olmasından kaynaklanmaktadır. Disiplin olarak ele alındığında arazi kullanımı, insan, çevre ve ekonomilerle ilgili kavramlar akla gelirken aslında planlama; daha iyi (daha adil, daha yaşanabilir, daha sürdürülebilir) bir gelecek için çalışmayı gerektirmektedir. Planlama eğitimi sadece kavramlarla değil daha iyi bir gelecek yaratmak için bu kavramların nasıl uygulanacağı yani planlama pratiği ile ilgilidir (Minnery, 2010). Bu sebeple dünyada olduğu gibi ülkemizde de planlama pratiği için eğitim programlarındaki uygulamalı derslerin başında planlama stüdyoları (atölye ve işlik olarak da adlandırılmaktadır) gelmektedir. Planlama stüdyoları genel olarak öğrencilerin belirli probleme çözüm geliştirdikleri ve daha sonra bu çözümü bir jüri (akademisyenler ve uzmanlar) önünde savundukları derslerdir. Bu tür bir eğitim müfredatının tasarlanmasındaki temel zorluklardan biri, öğrencilere uygun bir mantıksal çerçevede planlama süreçleri ve planlama becerilerini bir uygulama alanı üzerinden bütünleştirmektir (Lang, 1983). Bu nedenle stüdyolar açık uçlu bir problemle başlamaktadır ve genellikle gerçek kişiler ile gerçek dünyada, güncel sorunları dikkate almaktadır. Bir stüdyo dersi, öğrenci çalışmalarının değişen ölçeklerde ve üretken bir süreçte tekrar tekrar gözden geçirildiği, sıklıkla yinelendiği, çok yoğun bir çalışma düzenini gerektirmektedir (Long, 2012). Bu bağlamda planlama eğitiminde uygulamalı dersler ile teorik derslerin aslında birbirinin bütünleyicisi olduğu görülmektedir.

Deneyimsel, uygulamalı öğrenme derslerinin çeşitli sosyal ortamlara uyum, konuşma ve aktarım becerilerinin gelişimini teşvik ettiği bilinmektedir (Bridges, 1993). Nitekim stüdyo çalışmaları öğrencileri iletişim (grafik, görsel ve yazılı beceriler, sözlü sunum, planlar ile fiziksel gerçeklik arasındaki ilişkiyi anlama), profesyonel deneyim (uygulamada beklenen kalite standartlarını ve plancının çeşitli rollerini anlama), sentez, teori ile uygulama etkileşimi, problem çözme (mantıksal, savunulabilir planlama kararlarını, olası seçenekleri değerlendirme, muhalif bakış açılarını müzakere etme, eleştirel düşünme yeteneği geliştirme), takım çalışması (işbirliği geliştirme), hizmet ve etik (kamu yararının tanınması, değerlere dayalı planlama) konularında geliştirmektedir (Long, 2012; Heumann ve Wetmore 1984). Görüldüğü gibi planlama eğitiminde öğrenciler program hedeflerinden çok daha fazlasını öğrenmektedir (Roakes ve Norris-Tirrell, 2000). Kısaca sunum sanatı (yazılı, sözlü ve görsel), zaman yönetimi, bağımsız öğrenme, problem çözme, başkalarıyla etkin çalışabilme ve motivasyon gibi aktarılabilir beceriler (Haigh ve Kilmartin, 1999; Brown, 1999; May, 1999; Livingstone ve Lynch, 2000) ile bilgi çağının gerekliliği olan birkaç yabancı dile hakim olma, yazma ve konuşma becerilerinin geliştirilmesi, bilgisayar programlarına hakimiyet (grafik gösterimi, kantitatif analizler vb.), bilgi sistemlerinin kullanımı ve yazılım teknolojilerine adaptasyon plancılar için önem arz etmektedir (Castells, 1998).

Literatürde Şehir ve Bölge Planlama eğitimine ilişkin bilgi ve deneyimler detaylı olarak ele alınırken bu çalışmanın odaklandığı esas nokta planlama eğitiminde öğrencilerin fikirleri, kaygıları ve beklentileri üzerinedir. Nitekim çalışmada öğrencilerin ve profesyonel plancıların planlama eğitiminden 
beklentilerine, mesleğe başlamadan önceki (veya sonraki) tecrübelerine, umut ve korkularına, kendilerini mesleğe ne kadar hazır hissettiklerine cevap aranmaktadır.

\section{Kaygı, Beklenti ve Öz Yeterlilik Üzerine}

Kaygı nosyonu tehlike anında, beklenmedik zamanda, ne yapacağını bilememe durumu (Blair, 2014); fiziksel belirtileri olan, genellikle anormal ve nedensiz açığa çıkan aşırı korku hali (Millar ve Walsh, 2000); üzüntü, endişe duyulan düşünce ve tasa (URL-3); her bireyde farklı zamanlarda görülebilen ve fiziksel olarak kişiyi sıkıntıya sokan bir duygu veya duygular kümesi (Burkovik, 2013) olarak tanımlanmaktadır. Özellikle sürekli kaygı durumunda bireylerin başlarına kötü bir şey gelecek gibi hissettikleri görülmektedir (Taşğın vd., 2007). Tallis ve ark. (1992) ise kaygının tepkiselliği üzerinde durarak bireylerin işlerin iyi neticelenmeyeceğini anladıklarında kaygıya kapıldıklarını ve içsel bir alarm sisteminin harekete geçtiğini belirtmektedir. Bu durum yetenekleri küçümseme veya mükemmeli yakalama isteğinin bir sonucu olarak ortaya çıkabilmektedir (Yeşilyurt, 2007). Kaygıya birçok faktör sebep olabilmektedir ve bu faktörler bağlama göre çeşitlilik göstermektedir. Örneğin bireylere sağlanan desteğin çekilmesi, olumsuz bir sonucu beklemek, iç çelişki ve belirsizlik gibi durumlar (Cüceloğlu, 1993) kaygıya yol açtığı gibi; yaş, cinsiyet, ebeveyn tutumları, ebeveynlerin eğitim durumu ve mesleği, sosyo-ekonomik düzey, hanede yaşayan kişi sayısı vb. (Yenilmez ve Özbey, 2006) değişkenlerin de kaygıyı etkileyen faktörler olduğu bilinmektedir. Bu çalışmada genel kaygı bozukluklarından ziyade öğrencilerin sınav ve iş bulmaya yönelik kaygıları üzerinde durulmaktadır. Bu bağlamda Semerci (2007) sınav kaygısının en önemli sebeplerinden birini; her şeyin kötüleşeceğine ve sonucun bir felaket olacağına ilişkin yaratılan düşünce, inanç ve senaryolar olarak belirtmektedir. Sınav kaygısının diğer sebepleri kabul görmeme endişesi, sorumluluğu taşıyamama endişesi, rekabette geri kalma ve kontrol kaybı korkusudur (Yeşilyurt, 2007). Yükseköğretim mezunları arasında işsizlik oranlarının artışı ve gençlerin işgücü piyasasının talep ettiği donanımlara (yeterince) sahip olamadan mezuniyetleri ise beraberinde (pek çok üniversite öğrencisi açısından) işsizlik kaygısını getirmektedir (Çolakoğlu vd., 2017).

Çalışmada üzerinde durulan bir diğer kavram beklentilerdir. Aynı dersi, aynı zamanda alan ve aynı sınava tabi tutulan öğrencilerin başarısının, derse ilişkin memnuniyetlerinin birbirinden oldukça farklılaştığını tespit eden Appleton-Knapp ve Krentler (2006) bu durumu öğrencilerin derslere yönelik beklentilerine bağlamaktadır. Yeni lisans öğrencileri gerçekçi olmayan beklentilere sahip olabilirler ve eğer yükseköğretim kurumları bu tür öğrencilerin beklentilerini iyi anlıyorsa, onları hem yönetmek hem de gerçekçi bir seviyeye getirmek için çaba göstermelidir (Voss vd.,2007). Örneğin öğrenciler eğitimlerinden ve dolayısıyla öğretim görevlilerinden ne beklemeleri konusunda bilinçlendirebilir (Hill, 1995) ki bu durum öğretim programlarının tasarımında da yardımcı olabilir. Nitekim Hill (1995) genel olarak öğrenci beklentilerini eğitim-öğretim kalitesi, öğretim yöntemleri ve ders içeriği gibi akademik hizmetlerle ilişkilendirmiş ve bunların zaman içinde değişmediğini tespit etmiştir. Başka bir çalışmada Hill vd. (2003), yüksek kaliteli eğitim sağlamada öğretim üyelerinin niteliğinin en önemli faktör olduğunu belirtmektedir. Pozo-Munoz ve ark. (2000) öğretim üyelerinin bir üniversitenin çalışmasında kilit aktör olduğunu öne sürmektedir. Bazı ampirik çalışmalar öğretim üyesi ve öğrenci arasındaki olumlu algıların başarı düzeyini etkilediğini ileri sürmektedir (Goodenow, 1993; Osterman, 2000; Roeser vd., 1996). Nitekim okula ait algılar, akademik motivasyonla (Taylor, 1999), hedef yönelimi ve akademik öz yeterlilik (Roeser vd., 1996) ile ilişkilendirilmiştir.

Öz yeterlilik kavramını bilişsel kuram içerisinde sunan Bandura'ya (1977) göre öz yeterlilik; bireyin her durumda üstesinden gelerek başarılı olacağını düşünmesi ve kapasitesinin yeterli olduğuna inanmasına bağlıdır. Bireyin etkileşimden aldığı olumlu ve olumsuz dönüşler (mesajlar), yeterlilik beklentisine etki eden bir diğer unsurdur. Örneğin öz yeterlilik beklentilerinde, bir kişinin görevinin gerektirdiği becerileri taşıdığı ikna edici bir şekilde savunulduğu takdirde başarıda artış gözlenebilmektedir (Eysenck, 2000). Bandura (1994) birçok etmenin öz yeterliliği etkilediğini belirtmiştir ki bunların başında kavramsal veya analitik düşünme yetenekleri gelmektedir. Bireylerin yorucu, zor ve stresli durumla karşılaştıkları zaman bir işi yapma olasılıkları düşmektedir. Yüksek öz yeterliliğe sahip olanların daha zor hedefler seçeceklerini, analitik düşünme yetilerini sürdürebilecekleri ve verilen işleri zamanında ve başarıyla bitirecekleri belirtilmektedir (Aşkar ve Umar, 2001). 


\section{3. Çalışmanın Amaç, Kapsam ve Yöntemi}

Türkiye'de Şehir ve Bölge Planlama eğitiminin yapısına ve mesleki kaygılara ilişkin araştırmalar oldukça kısıtlıdır. Bu nedenle çalışmada planlama okullarındaki eğitim ve öğretim niteliğinin, eğitim sürecinin mesleki öz yeterliliğe etkisinin, iş bulmaya yönelik kaygıların, mezuniyet sonrası işe başlama süresinin, planlama mesleğine ilişkin beklentilerin ve meslek hayatında karşılaşılan güçlüklerin değerlendirilmesi amaçlanmaktadır. Ayrıca planlama okulları arasındaki tutum, kaygı ve beklenti farklılaşmalarının, mesleki tecrübede eğitim etkisinin, farklı statülerde çalışan plancıların mesleğin geleceğine yönelik düşüncelerinin belirlenmesi ise çalışmanın alt amaçları arasında yer almaktadır. Görüldüğü üzere bu çalışma geleceğin şehir plancısı olacak öğrencileri, onların mesleki eğitimlerine katkıda bulunan akademisyenleri ve farklı statüde çalışan mezun plancıları kapsamaktadır. Bu bağlamda ilk olarak planlama lisans öğrencilerine eğitim ve öğretimin niteliğine ilişkin tutumları, iş bulma kaygıları ve gelecek beklentilerini ölçmeyi hedefleyen bir anket çevrimiçi olarak sunulmuştur. Çalışma kapsamına eğitim-öğretim faaliyetlerinin aktif olarak devam ettiği tüm planlama okulları ve öğrencileri dâhil edilmiş, ancak yapılan ön testlerde (pilot anket çalışmasında) deneyim ve mesleki bilgi düzeylerinin kısıtılığı nedeniyle (sonuçları yanlış etkileyebileceği kaygısıyla) birinci, ikinci ve üçüncü sınıf öğrencilerine örneklemde yer verilmemiştir. Çalışma, hem eğitim süreçlerini daha objektif değerlendirebilmeleri hem de mesleki beklentilerin farklılaştığı ve iş bulma kaygılarının belirginleştiği saptanan son sınıf öğrencileri ile sınırlandırıııı̧tır. Çalışmada hâlihazırda 4. sınıf lisans öğrencisi bulunan 18 farklı üniversitedeki Şehir ve Bölge Planlama Bölümleriyle iletişime geçilmiş ve anketler yalnızca 2017-2018 eğitim-öğretim yılı bahar döneminde mezun olabilecek öğrencilere yaptırılmıştır.

Lisans öğrenci anketi sürecinde iki temel problem ile karşılaşılmıştır. Bu problemlerin ilki bazı bölümlerin mezun durumundaki öğrenci sayılarını bildirmek için dönüş yapmaması, bu nedenle çalışma evreninin varsayımsal olarak hesaplanmasıdır (kontenjanlar göz önünde bulundurularak her bölümde ortalama 60 mezun öğrenci olacağı varsayılmış ve örneklem sayısı 1080 olarak tahmin edilmiştir). Çalışmada evren büyüklügünün 1080 kişi kabulü ile \% 90 güven aralı̆ıında örneklem hesaplaması yapıldığında 217 kişi anketinin yeterli olduğu görülmektedir (çalışmada 246 kişi anketi bulunmaktadır). íkinci problem ise tarafımıza dönüş yapan öğrenci sayısının okullara göre eşit dağıım göstermemesidir. Ancak lisans öğrencilerinin ankete katılım oranındaki farklılıklar bölümlerin açılış yılına göre sınıflandırma yapıldığında (bu sınıflama ilerideki bölümde detaylı olarak anlatılacaktır) herhangi bir sorun teşkil etmemektedir. Nitekim tüm analizler üniversite ayrımından bağımsız olarak bu yeni sınıflama özelinden yapılmıştır.

Lisans öğrenci anketleri değerlendirilirken bazı soruların ve cevapların (özellikle eğitim-öğretim tutumlarına ilişkin) daha detaylı olarak incelenmesi gerekliliği ortaya çıkmış ve çalışmada dört üniversiteden gönüllü 9 öğrenci ile odak grup görüşmesi, üç üniversiteden gönüllü 6 akademisyen ile derinlemesine görüşme gerçekleştirilmiş, bu görüşmelerden çalışmanın bulgular ve sonuç bölümlerinde sıklıkla yararlanılmıştır.

Çalışmada ikincil olarak eğitim, mesleki öz yeterlilik ve iş tatmini arasındaki ilişki ile meslekte karşılaşılan güçlüklerin belirlenebilmesi için mezun şehir plancılarına yönelik bir anket çalışması daha gerçekleştirilmiştir. Burada hedef evrenden bağımsız olarak istihdama katılan ve kamu ya da özel sektörde şehir plancısı olarak çalışan kişilere yönelik anketler sanal bir platformda çevrimiçi olarak sunulmuş ve 54 katılımcının desteği alınarak çalışma tamamlanmıştır. Yine daha detaylı inceleme yapabilmek adına İstanbul, Ankara, İzmir, Mersin ve Konya'da çalışan 17 katılımcı ile derinlemesine görüşmeler gerçekleştirilmiştir (Şekil 1). 


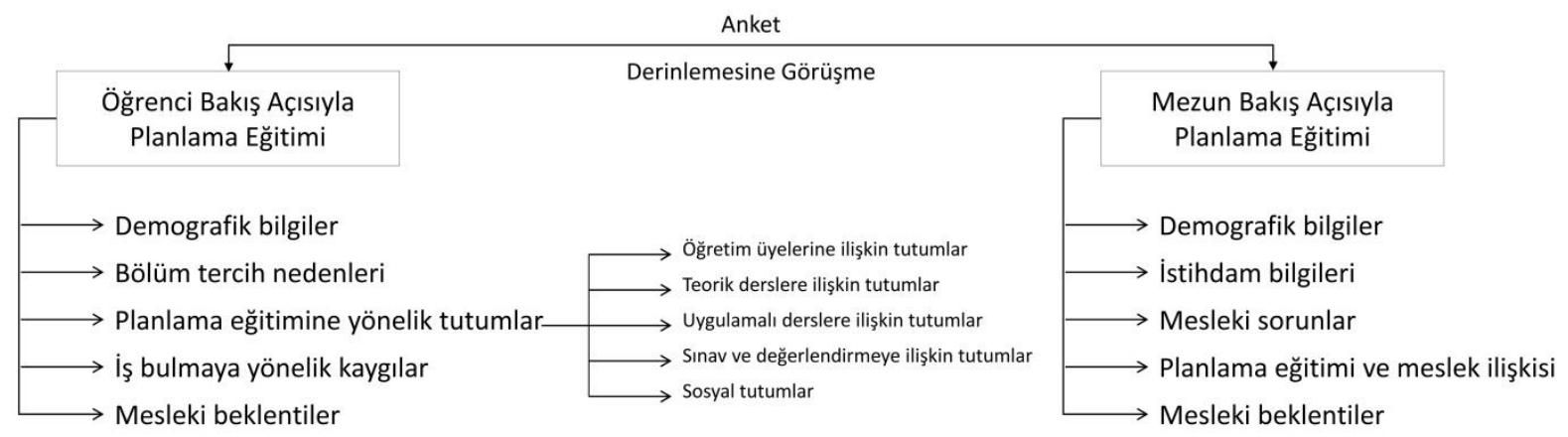

Şekil 1. Çalışmanın çatkısı

Çalışmada katıımcıların vermiş oldukları cevaplar doğrultusunda elde edilen veriler için iki ayrı veri seti oluşturulmuş, veriler SPSS Statistics 20 paket programı ile analiz edilmiş, tanımlayıcı ve çıkarımsal istatistikten yararlanılmıştır. Ayrıca beşli Likert ölçeği ile hazırlanan soruların değerlendirilmesinde aralıkların eşit olduğu varsayımıyla aritmetik ortalamalar için Çizelge 1'deki gibi bir değerlendirme sistemi kullanılmıştır.

Çizelge 1. Beşli Likert ölçeğine göre aritmetik ortalamaların değerlendirme aralığı

\begin{tabular}{clll}
\hline Puan & Aralık & Seçenekler & Değerlendirme \\
\hline 1 & $1,00-1,80$ & Kesinlikle Katılmıyorum & Çok Düşük \\
2 & $1,81-2,60$ & Katılmıyorum & Düşük \\
3 & $2,61-3,40$ & Kararsızım & Orta \\
4 & $3,41-4,20$ & Katılıyorum & Yüksek \\
5 & $4,21-5,00$ & Kesinlikle Katılıyorum & Çok Yüksek \\
\hline
\end{tabular}

Çalışmada yönlendirme yapmamak ve yanlış okumalara sebep olmamak için katılımcılara tüm soru kalıplarında olumlu cümleler sunulmuş ancak değerlendirmelerde ortalamaların alınabilmesi için bazı önermeler olumsuz cümleye çevrilerek tekrar hesaplama yapılmıştır.

\section{Araştırmanın Bulguları}

Araştırmanın bulguları değerlendirilirken ilk başlıkta öğrencilerin eğitim gördükleri bölümler eğitimöğretime başlama tarihleri temel alınarak sınıflandırılmış ve analizler bu sınıflama üzerinden gerçekleştirilmiştir. 25 yıl ve daha uzun süre eğitim veren bölümlerin I. Dönemi, 10-24 yıldır eğitim veren bölümlerin II. Dönemi, 10 yıldan az süredir eğitim veren bölümlerin III. Dönemi oluşturduğu bu sınıflamanın amacı; planlama okulları arasında görece kısa, orta ve uzun dönemlerde anlamlı farklılaşmalar olup olmadığının tespit edilebilmesidir. Çalışmanın bu başlığında eğitim ve öğretime ilişkin öğrencilerin olumlu ya da olumsuz tutumlarını belirleyebilmek amacıyla öğretim üyelerine (8 ölçüt), teorik (6 ölçüt) ve uygulamalı derslere (10 ölçüt), sınav ve değerlendirmelere (5 ölçüt), sosyal ilişkilere (4 ölçüt), iş bulma (5 ölçüt) ile mesleki kaygı düzeylerine ( 7 ölçüt) yönelik 7 başlıkta toplam 45 ölçüt üzerinden bir değerlendirme gerçekleştirilmiştir.

Ikinci başlıkta ise istihdama katılan profesyonel plancıların meslek hayatında karşılaştıkları güçlüklere, öz yeterlilik ve planlama eğitimine ilişkin görüşlerine yer verilmiştir. Örneklem küçüklüğü nedeniyle istihdama katılan profesyonel plancıların mezun oldukları okullara ilişkin herhangi bir sınıflama yapılmamıştır.

\section{1. Öğrencilerin bakış açısıyla planlama eğitimi}

Bu başıkta katılımcıların demografik bilgileri, bölüm tercih nedenleri, planlama eğitimine yönelik tutum, kaygı ve beklentilerine ilişkin bulgular değerlendirilmektedir.

Illk olarak katılımcıların demografik bilgileri incelendiğinde ankete katılan toplam 246 öğrencinin \% 69,8'inin kadın, \% 30,2'sinin erkek olduğu görülmektedir. Örneklemde yaş aralığı 21-27 arasında değişmektedir ve ortalama yaş 23,1 olarak tespit edilmiştir. Katılımcıların \% 29,4'ü 25 yıl ve üzeri, \% 38,7'si 10-24 yıl, \% 31,9'u 10 yıldan daha az bir süredir planlama eğitimi veren bölümlerde öğrenimlerine devam etmektedir (Çizelge 2). 
Çizelge 2. Üniversitelere göre ankete katılan öğrencilerin dağılımı (\%)

\begin{tabular}{lrlrlr}
\hline I. Dönem (25 yıl ve üzeri) & & II. Dönem (10-24 yıl) & & \multicolumn{2}{l}{ III. Dönem (10 yıldan daha az) } \\
\hline Orta Doğu Teknik Ü. & 3,2 & Bozok Ü. & 9,7 & Atatürk Ü. & 8,9 \\
Dokuz Eylül Ü. & 2,4 & İzmir Yüksek Teknoloji E. & 1,6 & Kırklareli Ü. & 4,0 \\
Gazi Ü. & 6,5 & Karadeniz Teknik Ü. & 2,0 & Mersin Ü. & 5,6 \\
İstanbul Teknik Ü. & 4,4 & Erciyes Ü. & 8,5 & Necmettin Erbakan Ü. & 10,5 \\
Yıldız Teknik Ü. & 9,3 & Konya Teknik Ü. & 15,3 & Pamukkale Ü. & 2,4 \\
Mimar Sinan Ü. & 3,6 & Süleyman Demirel Ü. & 1,6 & Amasya Ü. & 0,4 \\
\hline I. Dönem Toplamı & $\mathbf{2 9 , 5}$ & II. Dönem Toplamı & $\mathbf{3 8 , 7}$ & III. Dönem Toplamı & $\mathbf{3 1 , 8}$ \\
\hline
\end{tabular}

Bölüm tercih nedenlerine ilişkin katılımcılara 'Şehir ve Bölge Planlama Bölümünü neden tercih ettiniz?' sorusu sorulduğunda mesleğe olan ilgiden dolayı tercih yapanların oranının \% 41,7 olduğu görülmektedir. III. ve II. Dönem planlama okullarında iş bulmaya yönelik beklentinin daha yüksek olduğu söylenebilir (Çizelge 3).

Çizelge 3. Şehir ve Bölge Planlama Bölümü tercih nedenleri (\%)

\begin{tabular}{rrrrr}
\hline & $\begin{array}{r}\text { Eş, dost, akraba vd. } \\
\text { tavsiyesi ile }\end{array}$ & $\begin{array}{r}\text { Mesleğe olan ilgimden } \\
\text { dolayı }\end{array}$ & $\begin{array}{r}\text { İş bulma olanaklarının } \\
\text { fazla olması nedeniyle }\end{array}$ & Diğer \\
\hline I. Dönem & 37,2 & 41,9 & 4,6 & 16,3 \\
II. Dönem & 46,5 & 38,1 & 11,2 & 4,2 \\
III. Dönem & 30,9 & 45,4 & 16,4 & $\mathbf{7 , 3}$ \\
\hline Toplam & $\mathbf{3 8 , 4}$ & $\mathbf{4 1 , 7}$ & $\mathbf{1 1 , 1}$ & $\mathbf{8 , 8}$ \\
\hline
\end{tabular}

\subsubsection{Planlama öğrencilerinin öğretim üyelerine ilişkin tutumları}

Planlama öğrencilerinin öğretim üyelerine yönelik tutumları 8 önerme ile saptanmaya çalışılmaktadır. Bu bağlamda ilk olarak öğretim üyeleri ile rahat ilişki kurabilirim önermesi ele alınmaktadır ve bu önermeye öğrencilerin \% 37,0'ının katılıyorum, \% 24,0'ının kesinlikle katılıyorum yanıtını verdiği görülmektedir. Ankete katılan öğrencilerin \% 34,6’sı öğretim üyeleri öğrencilere ders dışında da zaman ayırırlar önermesine katılıyorum, \% 16,1'i ise kesinlikle katılıyorum yanıtını vermiştir. Likert ölçeği ortalamaları incelendiğinde I. Dönem planlama okullarında öğretim üyelerinin öğrencilere ders saatleri dışında daha çok zaman ayırdığı görülmektedir (Şekil 2). Bu durum öğretim üyesi başına düşen öğrenci sayısı ile ilişkilendirilebilir (görece daha yeni bölümlerde öğretim üyesi sayısı az, öğrenci sayısı fazladır). Bölümlerdeki kontenjanların yatay ve dikey geçiş yapan öğrenciler de eklendiğinde her sene katlanarak artmasının, öğretim üyelerinin öğrencilerine zaman ayırmasını güçleştiren önemli bir etken olduğu unutulmamalıdır (öğretim üyesi başına lisans öğrenci sayıları dünyadaki diğer planlama okullarında oldukça düşüktür. Danimarka Aalborg'da 3,75 Almanya Dortmund'da 3,17 italya Torino'da 4,62 iken (TUPOB, 2007) ülkemizde bu sayı 15-75 arasında değişmektedir).

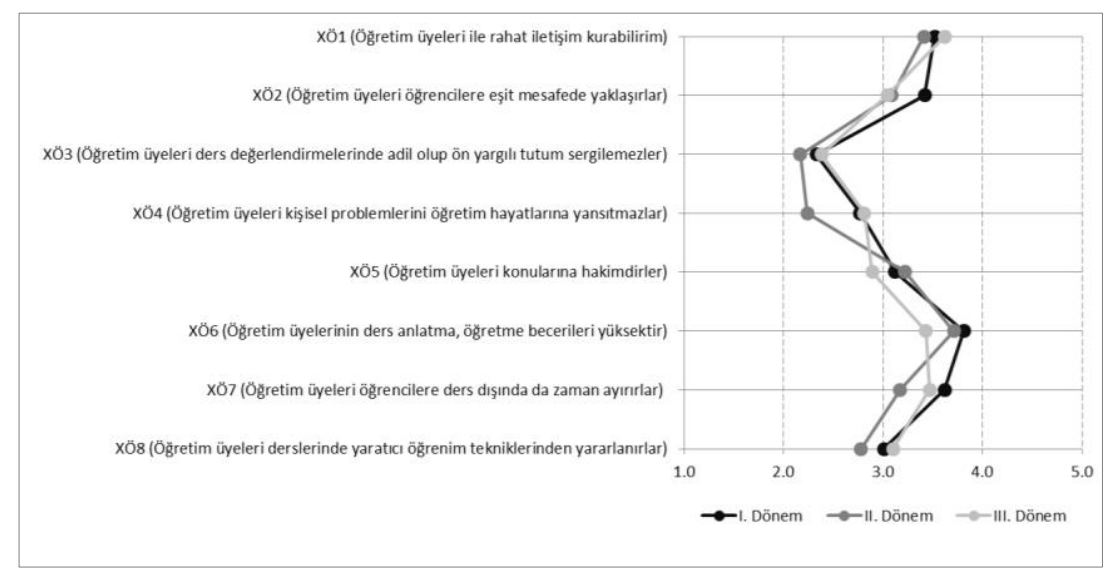

Şekil 2. Planlama öğrencilerinin öğretim üyelerine ilişkin tutumları

Planlama eğitimini diğer meslek disiplinlerinden ayıran en temel fark bilindiği gibi eğitim programlarında ağırlıklı olarak yer alan uygulamalı derslerin bulunmasıdır. Bu dersler hemen hemen tüm planlama okullarında yüksek bir krediye sahiptir (tüm bölümlerdeki öğrenci iş yüklerine göre 
hesaplanan Avrupa Kredi Transfer Sistemi / AKTS dikkate alınmıştır). Bu derslerde her ne kadar planlamanın temel ilkelerini esas alan, nesnel bir değerlendirme yapılmaya çalışılsa da sübjektif yargılardan tam olarak soyutlanmanın mümkün olmadığı görülmektedir. Bu nüans planlama öğrencilerinin öğretim üyelerinin öğrencilere eşit mesafede davranma ve adil not verme konusundaki güvenini bazı durumlarda zedeleyebilmektedir. Bu bağlamda ankete katılan öğrencilerden öğretim üyelerinin öğrencilere eşit mesafede yaklaşımı ve ders değerlendirmelerinde adil olup olmadıkları hususlarını değerlendirmeleri istenmiştir. Katılımcıların \% 61,4'ü öğretim üyeleri öğrencilere eşit mesafede yaklaşırlar önermesini reddetmektedir. Benzer şekilde, öğretim üyeleri ders değerlendirmelerinde adil olup ön yargılı tutum sergilemezler önermesini katılımcıların \% 24,4'ü kesinlikte katılmıyorum ve \% 25,2'si katılmıyorum olarak yanıtlarken yalnızca \% 6,7'si değerlendirmelerin adil bir şekilde yapıldığını düşünmektedir. Diğer bir ölçüt olan öğretim üyeleri kişisel problemlerini öğretim hayatlarına yansıtmazlar sorusuna ise katılımcıların \% 57,2'si olumsuz yanıt vererek öğretim üyelerinin kişisel problemlerinden izole olamadığını ve bunu derslerine yansıttıklarını belirtmektedir.

Bu bölümde son olarak öğretim üyelerinin ders anlatma yeteneklerine ilişkin üç ölçüt yer almaktadır. Bunların ilki öğretim üyeleri konularına hâkimdir önermesidir ve Likert ölçeği ortalamasına göre yüksek düzeyde $(\bar{x}=3,63)$ katılım yanıtı alınmıştır. Ölçütlerin ikincisi öğretim üyelerinin ders anlatma, öğretme becerileri yüksektir önermesidir ve katılımcıların \% 37,4'ü olumlu \% 29,5'i kararsız görüş bildirmiştir. Üçüncül olarak öğretim üyelerinin derslerinde yaratıcı öğrenim tekniklerinden yararlanırlar önermesine ise katılımcıların \% 33,1'i olumlu dönüş yapmıştır.

\subsubsection{Planlama öğrencilerinin teorik derslere ilişkin tutumları}

Planlama öğrencilerinin teorik derslere ilişkin tutumlarını belirlemeye yönelik hazırlanan 6 ölçüt ile amaçlanan; (derslerin içeriğinin sorgulanması değil) öğrencilerin verilen dersler ile mesleki bağıntıyı kurup kuramadıklarının tespit edilmesidir. Bu bağlamda önermelerin ilki teorik derslerin içeriği planlama mesleğine yöneliktir olmuş ve katılımcıların \% 70,8'i bu önermeye olumlu görüş bildirmiştir. Mesleki bağıntı I. Dönem planlama okullarında nispeten daha yüksek düzeydedir $(\bar{x}=3,78)$.

Planlama eğitimi süresince teorik ve uygulamalı dersler birbirinden bağımsız düşünülemez bir bütün olup, teorik derslerde elde edilen bilgi ve becerilerin uygulamalı derslerde pratiğe aktarılması hedeflenmektedir. Bu nedenle ders yükü oldukça yoğun olan uygulamalı derslerin (şehircilik projesi, kentsel tasarım, peyzaj planlaması, mimarlık bilgisi, fiziksel çevre kontrolü vb.) yanı sıra planlama eğitimi boyunca birçok teorik dersin öğretim programlarında yer aldığı görülmektedir. Bu bağlamda planlama öğrencilerine teorik derslerde edinilen bilgi ve beceriler uygulamalı derslere destek olacak niteliktedir önermesi yöneltilmiş ve \% 43,3 oranında katılım cevabı alınmıştır. Teorik bilginin uygulama yapabilmek için bir zorunluluk olduğu görüşüne öğrenciler orta düzeyde katılmaktadır $(\bar{x}=3,32)$. Hâlbuki teorik bilgilerin uygulama alanında kullanabilmesi planlama okullarının ortak amacını oluşturmaktadır.

Katılımcıların \% 53,4'ü verilen teorik derslerin ders yükünü fazla bulmaktadır. Bu durum teorik derslerin fazlasıyla sunum, ödev vb. etkinlikleri içermesiyle ilişkilendirilebilir. Teorik derslere yönelik bir diğer önerme teorik derslerin içeriği günümüz gelişmelerini takip ederek yenilenmektedir olup katılımcıların yalnızca \% 39,4'ü olumlu görüş bildirmiştir. Likert ortalamaları dikkate alındığında I. Dönem planlama okullarının II. ve III. Dönemlere göre daha yenilikçi olduğu görülmektedir (Şekil 3). Akademisyenlerin güncel gelişmeleri takip ederek derslerini hazırlaması özünde bireysel sorumluluk, nitelik ve mesleki etik ile ilişkilendirilebilir ancak öğretim üyesi başına düşen ders sayısı artıkça literatüre olan hâkimiyetin azalacağı da unutulmamalıdır. Nitekim daha az ders yüküne sahip öğretim üyelerinin daha fazla zamana sahip olması literatürdeki gelişmeleri takip edebilmelerinde ve ders içeriklerini güncel gelişmelere göre yenilemelerinde kolaylık sağlayıcı bir durumdur. 


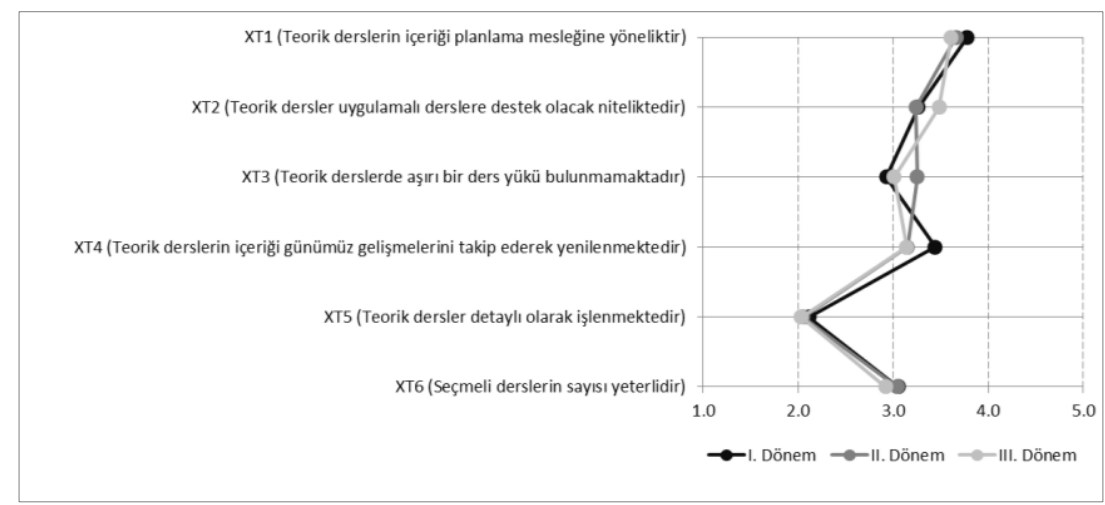

Şekil 3. Planlama öğrencilerinin teorik derslere ilişkin tutumları

Katılımcıların \% 64,2'si teorik dersler detaylı olarak işlenmektedir önermesini reddederken; seçmeli derslerin sayısı yeterlidir önermesine \% 34,3'ünün katılıyorum, \% 10,6'sının kesinlikle katılıyorum yanıtını verdiği görülmektedir. Likert ortalamalarına göre (Şekil 3) III. Dönem planlama okullarında seçmeli ders sayılarının görece daha az olduğu ve derslerin detaylı işlenmediği söylenebilir.

\subsubsection{Planlama öğrencilerinin uygulamalı derslere ilişkin tutumları}

Planlama mesleği çeşitli ölçeklerde (ulusal, bölgesel, kentsel, kırsal vb.) ve farklılaşan konularda (çevre, konut, altyapı, rekreasyon, koruma, ulaşım vb.) plan ve projeleri kapsadığı için her bölümün müfredatında uygulamalı dersler önemli bir yere sahiptir. Bu bağlamda planlama öğrencilerinin uygulamalı derslere ilişkin tutumlarını değerlendirmek amacıyla 10 ölçüt hazırlanmıştır. İlk olarak uygulamalı derslerin içeriği planlama mesleğine yöneliktir önermesi incelenmiş, katılımcılar planlama mesleği ile uygulamalı dersler arasında kuvvetli bir bağ olduğunu ifade etmiştir (bu önermeye katılımcıların yalnızca \% 8,0'ı olumsuz görüş belirtmiştir). Benzer bir diğer önerme uygulamalı dersler iş hayatına hazırlık niteliğindedir olmuş ve katılımcılar yine olumlu görüş bildirmiştir. Uygulamalı derslerin teorik dersleri pratikte uygulama imkânı sağlaması konusunda ise \% 65,3 oranında bir katıım söz konusudur. Uygulamalı derslerin meslekle bağıntısı I. Dönem okullarda daha yüksek düzeyde kurulmaktadır, bunu sırası ile II. ve III. Dönem okulları takip etmektedir (Şekil 4).

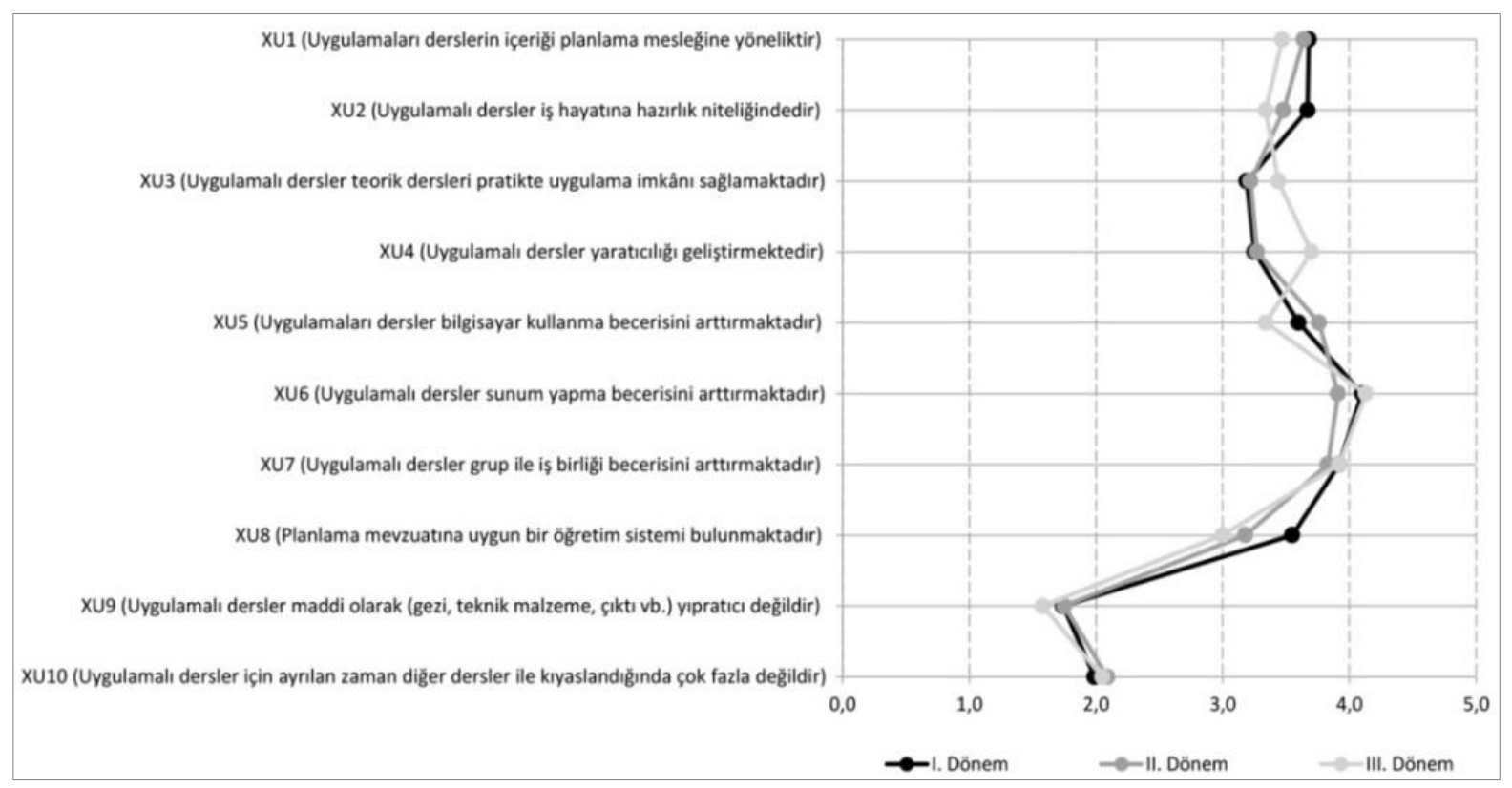

Şekil 4. Planlama öğrencilerinin uygulamalı derslere ilişkin tutumları

Bilindiği gibi uygulamalı derslerde yaratıcılığın geliştirilmesi ve öğrencilerin çeşitli beceriler elde etmesi amaçlanmaktadır. Bu bağlamda katılımcıların \% 72,2'si uygulamalı derslerin yaratıcılığ desteklediğini, \% 79,7'si bilgisayar kullanım becerisini arttırdığını, \% 90,4'ü sunum yapma becerisini geliştirdiğini, \% 87,8'i grup ile iş birliği becerisi kazandırdığını belirtmektedir. Bu önermelere yüksek 
düzeyde katılım gözlenirken uygulamalı derslerde planlama mevzuatının yeterli düzeyde işlenmesi hususunda orta düzeyde bir katılım söz konusudur.

Katılımcılar bu başlıkta uygulamalı derslere ilişkin temelde iki negatif görüş bildirmiştir. Bunların ilki stüdyo derslerinde alan araştırması için başka kentlere yapılan araştırma gezileri ile teknik malzeme ve çıktılar için gerekli olan maliyetin yıpratıcı olmasıdır (\% 84,8). İkincisi ise uygulamalı dersler için ayrılan zamanın diğer dersler ile kıyaslandığında oldukça fazla bulunmasıdır (\% 90,7). Maddi eleştiriler III. Dönem, zaman eleştirisi ise II. Dönem planlama okullarında daha yüksek düzeydedir (bkz. Şekil 4).

\subsubsection{Planlama öğrencilerinin sınav ve değerlendirmeye ilişkin tutumları}

Planlama öğrencilerinin sınav ve değerlendirmeye ilişkin tutumlarını belirlemeye yönelik 5 ölçüt hazırlanmıştır. Bulgularda planlama öğrencilerinin bu başlığa ilişkin temel eleştirisi uygulamalı derslerde objektif değerlendirmenin yapıl(a)mıyor oluşudur. Nitekim uygulamalı derslerde objektif bir değerlendirme söz konusudur önermesini katılımcıların \% 13,1'i katılıyorum ve \% 10,4'ü kesinlikle katılıyorum şeklinde yanıtlarken, \% 76,5'i önermeyi reddetmektedir. Bu görüş I. Dönem planlama okullarında biraz daha baskındır (Şekil 5). Benzer bir durum teorik dersler için de bildirilmiş katılımcıların yalnızca \% 25,0'ı teorik derslerde objektif bir değerlendirmenin yapıldığını ifade etmiştir.

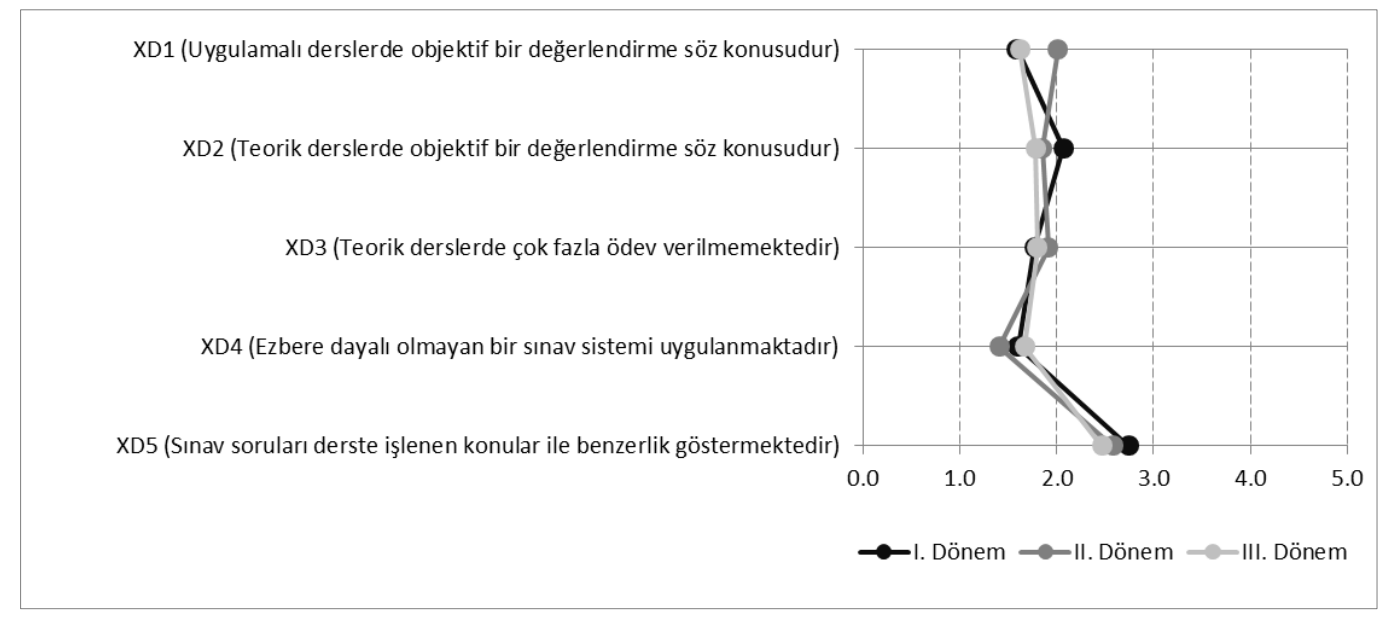

Şekil 5. Planlama öğrencilerinin sınav ve değerlendirmeye ilişkin tutumları

Katılımcıların \% 46,5'i teorik derslerde çok fazla ödev verildiğini, \% 58,1'i ezbere dayalı bir sınav sistemi uygulandığını ve \% 63,4'ü sınav soruları ile derste işlenen konuların benzerlik göstermediğini belirtmektedir. Görüldüğü üzere öğrenciler arasında sınav sistemine ve değerlendirme yöntemlerine ilişkin kaygı düzeyi yüksektir.

\subsubsection{Planlama öğrencilerinin sosyal ilişkilere yönelik tutumları}

Bu başlıkta planlama öğrencilerinin sosyal ilişkilerine odaklanılmıştır. Bilindiği gibi insanlar yaşamlarında diğer insanlarla ilişki kurmaya ve etkileşim içinde olmaya ihtiyaç duymaktadır. Ancak günümüzde bireylerin etkileşimleri sosyal medya, değişen dünya düzeni, metalaşma vb. birçok sebepten dolayı sekteye uğramaktadır (Kılıç ve Sevim, 2005). Bu noktadan hareketle 'Gençler arasında sıklıkla görülen giderek yalnızlaşma yoğun çalışma saatlerine maruz kalan planlama öğrencilerinin de karşılaştığı bir sorun mudur?' sorusuna cevap aranmaktadır. Bu amaçla dört ölçüt oluşturulmuş ve ilk olarak katılımcılara planlama eğitiminin bireyselliği, bencilliği ve çıkar ilişkilerini arttırdığı önermesi yapılımıştır. Bu önermeye öğrencilerin \% 53,5'i katılırken, \% 14,2'si karasız görüş bildirmiştir. Planlama öğrencileri arasında arkadaşını dışlama ve gruplaşma eğilimi diğer bölümlere göre yüksektir önermesine ise \% 66,9 katııım, \% 10,8 karasız yanıtları verilmiştir. Bu durum aslında planlama eğitimi süreci ile de ilişkilendirilebilir. Nitekim tüm planlama okullarında şehircilik projesi başta olmak üzere uygulamalı derslerde grup çalışması yapılmaktadır. Öğrenciler değerlendirme aşamasında genellikle birbirleri ile kıyaslandıklarını, göreli puanlama yapıldığını ve dolayısıyla rekabetin açığa çıktığını, böylece üzerlerinde psikolojik bir baskı oluştuğunu ifade etmektedir (\% $84,2)$. Sıralanan bu üç ölçütün I. Dönem okullarında diğerlerine kıyasla daha düşük olduğu görülmektedir (Şekil 6). 


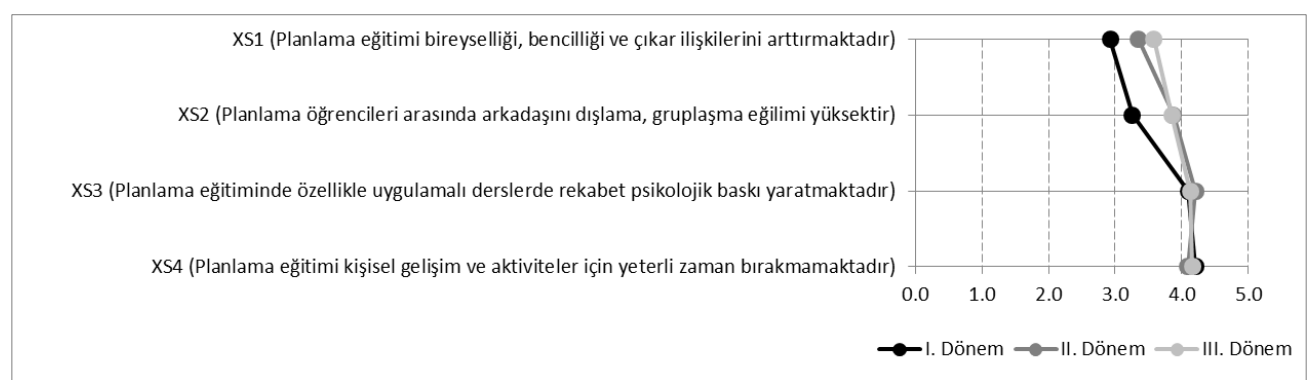

Şekil 6. Planlama öğrencilerinin sosyal ilişkilere ilişkin tutumları

Uygulamalı ders saat ve yüklerinin fazlalığı nedeniyle öğrencilerin sürekli stüdyolarda zaman geçirmesi daha dar bir sosyal ağ içinde yer almalarına sebep olmaktadır. Ayrıca öğrencilerin kişisel gelişim ve sosyo-kültürel aktiviteler için yeterli zamana sahip olmamaları $(\% 82,3)$ toplumsal ilişkiler bağlamında kaygı vericidir.

\subsubsection{Planlama öğrencilerinin iş bulma ve mesleki kaygı düzeyi}

Çalışmanın bu başlı̆ında katılımcıların iş bulma endişeleri ve mesleki kaygı düzeylerinin belirlenebilmesi amacıyla iş bulma, işe alınma, mesleki öz yeterlilik ve etik değerler hakkındaki düşünceler değerlendirilmektedir. Bu bağlamda katılımcılara ilk olarak 'iş̧ bulmak sizin için neden önemli?' sorusu yöneltilmiştir.

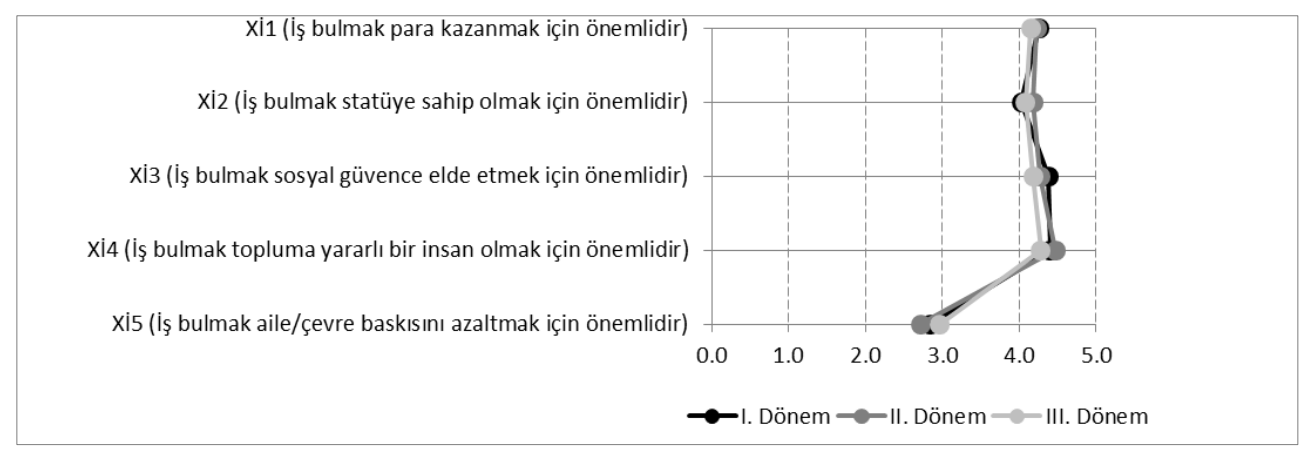

Şekil 7. İstihdama katılım hakkındaki görüşler

Katılımcılar tarafından iş bulmanın topluma yararlı bir insan olmak için önemli olduğunun öncelikli olarak ifade edilmesi planlamanın geleceği açısından umut vadetmektedir. Diğer yanıtlar sosyal güvence elde etmek, para kazanmak ve toplumda kabul gören bir statüye sahip olmak olarak sıralanmaktadır. Planlama öğrencileri üzerinde iş bulmaya yönelik herhangi bir aile baskısından söz etmek mümkün değildir (Şekil 7).

Planlama öğrencileri çalışma hayatına katılmak için oldukça istekli olmakla birlikte bu konuda yüksek kaygı düzeyine sahiptirler. Nitekim mezun olduktan sonra rahatlıkla iş bulabilirim önermesine yalnızca \% 14,3'ünün olumlu yanıt verdiği görülmektedir. Kamu kurumlarında işe girmenin zorluğu (sınav başarısı, sınırlı sayıda kontenjan vb. nedenlerle), artan mezun sayısına bağlı olarak özel sektördeki doygunluk göz önünde bulundurulduğunda mezunların bu kaygıları oldukça beklenen bir durumdur. Mezun olduktan sonra kendi mesleği dışında çalışmayacağını düşünenlerin oranı yalnızca \% 32,7'dir. Planlama mesleği için gerekli teorik ve pratik bilgi düzeyine eğitimlerini tamamladıktan sonra ulaşacağını düşünenlerin oranı \% 30,8 iken I. Dönem planlama öğrencilerinin bu konuda daha özgüven sahibi olduğu söylenebilir (Şekil 8). Katılımcıların \% 57,7'si planlama mesleği için gerekli teknolojiyi (bilgisayar programlarını) kullanabildiğini belirtirken III. Dönem planlama öğrencilerinin bu konuda kendilerini biraz daha yetersiz gördüğü belirlenmiştir (Şekil 8). 


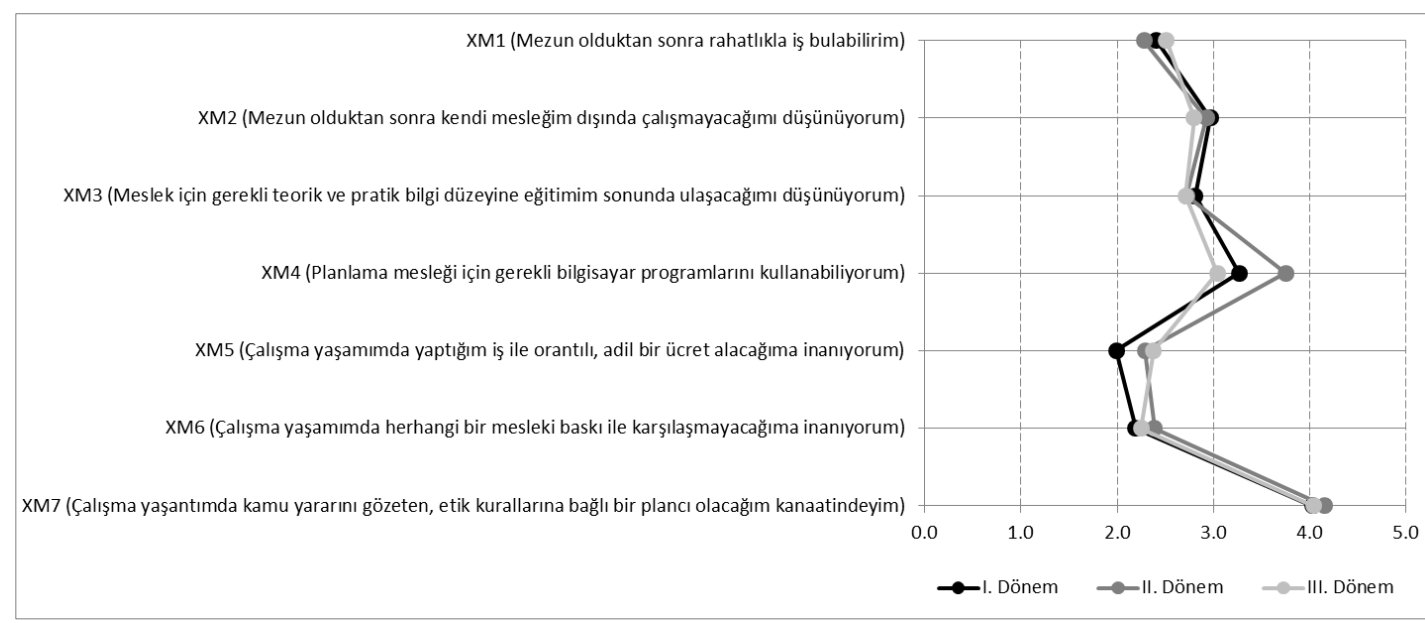

Şekil 8. Planlama öğrencilerinin iş bulma ve mesleki kaygı düzeyi

Çalışma yaşamına ilişkin beklenti ve kaygılar incelendiğinde (Şekil 8; XM5, XM6, XM7) örneklemde adil ücret alma ve mesleki baskı konularında çeşitli endişelerin varlığı gözlenmektedir. Çalışma yaşamımda yaptığım iş ile orantılı, adil bir ücret alacağıma inanıyorum önermesine katılımcıların \% 86,2'si çalışma yaşamımda işveren tarafından işime saygılı olunacağına ve herhangi bir baskı ile karşılaşmayacağıma inanıyorum önermesine ise katılımcıların \% 86,5'i olumsuz görüş bildirmiştir. Adil ücret ve mesleki baskılar konusunda I. Dönem planlama öğrencilerinin kaygı düzeylerinin diğerlerine nazaran daha yüksek olduğu söylenebilir (Şekil 8). Maier (1994) profesyonellere (plancı, kamu yönetimindekiler, politikacılar) gerekli bilgi ve teknik becerilerin sağlanmasının yanı sıra eğitimlerinde değer ve etik bilincinin arttırılması gerektiğini savunur. Bu bağlamda sıralanan kaygılara rağmen katılımcıların \% 79,6'sının çalışma yaşantılarında kamu yararını gözeten, etik kurallara bağlı bir plancı olacağı kanaatini taşımaları mesleğe dair umutlarının devam ettiğinin ve kendilerine inandıklarının bir göstergesidir.

Bu başlıkta son olarak katılımcılara kamu ve özel sektör iş alımlarında etkili kriterler sorulmuştur (Çizelge 4). Katılımcılar kamu sektöründe istihdam edilebilmek için sırasıyla siyasi referansların (\% 69,1), aile, akraba, arkadaş vb. referansların (\% 13,8), Kamu Personeli Seçme Sınavı (KPSS) puanının (\% 11,8) etkili olduğunu ifade etmektedir. Mesleki bilgi, beceri ve kişisel çabanın (\% 5,3) kamu sektöründe çalışmak için tek başına yeterli olmadığının düşünülmesi öğrencilerin çalışma ve başarılı olma isteğine ket vurabilecek bir algıdır. Ne yazık ki özel sektörde de benzer bir durum söz konusudur ve katılımcıların \% 87,5'i işe alınmada siyasi ve diğer referansların daha etkili olduğunu ifade etmektedir.

Çizelge 4. İş alımlarında etkili kriterler (\%)

\begin{tabular}{ccrrrr}
\hline & & $\begin{array}{c}\text { Siyasi } \\
\text { referanslar }\end{array}$ & $\begin{array}{r}\text { Aile, akraba, arkadaş } \\
\text { vb. referanslar }\end{array}$ & $\begin{array}{r}\text { Mesleki bilgi, } \\
\text { beceri ve kişisel } \\
\text { çaba }\end{array}$ & KPSS puanı \\
\hline \multirow{2}{*}{ Kamu } & I.Dönem & 69,0 & 18,3 & 8,5 & 4,2 \\
Sektörü & II.Dönem & 66,7 & 13,5 & 13,5 & 6,2 \\
& III.Dönem & 72,2 & 10,1 & 12,7 & 5,1 \\
\hline \multirow{2}{*}{ Özel } & I.Dönem & 47,9 & 43,8 & 2,7 & 5,5 \\
Sektör & II.Dönem & 45,8 & 43,8 & 9,4 & 1,0 \\
& III.Dönem & 50,6 & 30,4 & 15,2 & 3,8 \\
\hline
\end{tabular}

\subsubsection{Geleceğe yönelik mesleki beklentiler}

$\mathrm{Bu}$ başlıkta katılımcılara iş deneyimleri, iş sektörü ve maddi beklentiler olmak üzere üç soru yöneltilmiştir. Bunların ilki 'Planlama alanında ilk profesyonel iş deneyiminizin mezun olduktan kaç yıl sonra olacağını düşünüyorsunuz?' sorusudur ve çoğunlukla 1-3 yıl içerisinde $(\% 75,3)$ yanıtı alınmıştır. I. Dönem planlama okullarında çalışma hayatına daha erken sürede başlama beklentisinin yüksek olduğu görülmüştür $\mathrm{ki}$ bu durum büyük şehirlerdeki planlama bürolarının çokluğu ile ilişkilendirilebilir. İkincil olarak yöneltilen 'Kendinizi 5 yıl sonra hangi sektörde görüyorsunuz?' sorusuna katılımcıların \% 27,3'ü kamu çalışanı, \% 14,1'i belediye çalışanı, \% 19,0'ı uzman, \% 8,1'i 
işveren, \% 18,1'i özel sektör çalışanı, \% 4,4'ü akademisyen yanıtını verirken \% 8,9'u planlama mesleğine devam etmeyerek farklı bir sektörde yer alacağını belirtmektedir. Katılımcıların bu beklentilerinde de planlama okullarına göre farklılaşmalar mevcuttur; I. dönem planlama öğrencileri uzman olarak çalışacağını (\% 24,7), II. (\% 28,1) ve III. (\% 32,9) Dönem planlama öğrencileri ise kamu çalışanı olacağını öngörmektedir. Son olarak katılımcılara 'Çalışma yaşamınızda maddi beklentiniz nedir?' sorusu yöneltilmiş ve bu soruya katılımcıların \% 54,8'i 3001-5000 TL, \% 25,8'i 5001-7500 TL, \% 10,5'i 2000-3000 TL, \% 6,5'i 7501 TL ve üzeri, \% 2,4'ü ise asgari ücret yanıtını vermiştir.

\subsection{Profesyonel Bakış Açısıyla Planlama Eğitimi}

Çalışmanın ikinci aşamasında istihdama katılan 54 kent plancısı ile mezun anketi gerçekleştirilmiştir. Katılımcıların \% 57,4'ünü Gazi, \% 11,1'ini ODTÜ, \% 9,3'ünü Erciyes ve \% 7,4'ünü Dokuz Eylül Üniversitesi mezunları oluşturmaktadır. Katılımcıların yaşı 23-47 aralığındadır (yaş ortalaması 30,5'tir). Katılımcıların cinsiyet dağılımı incelendiğinde \% 51,9'unun kadın, \% 48,1'inin erkek olduğu görülmektedir. Katılımcıların \% 29,6'sı özel büro, \% 27,8'i kamu, \% 24,1'i belediye çalışanı, \% 9,3'ü özel büro sahibi, \% 5,6'si akademisyen, \% 3,7'si ise gayrimenkul ve değerleme uzmanıdır. Çalışanların $\%$ 68,5'inin planlama dışında başka bir iş deneyimi bulunmazken, \% 66,7'si 0-1 yıl, \% 14,8'i 2-3 yıl, \% $18,5^{\prime} i$ ise 4 yılı aşkın bir süredir mesleğini devam ettirmektedir.

Katılımcıların gelir düzeyi incelendiğinde \% 11,1'inin asgari ücret, \% 16,7'sinin 2000-3000 TL, \% 44,4'ünün 3001-5000 TL, \% 27,8'inin ise 5001 TL ve daha üzeri gelire sahip olduğu gözlenmiştir. Özel büro sahipleri ile işe yeni başlayanlar göz ardı edildiğinde ortalama ücretin 3001-5000 TL aralığında olduğu görülmektedir. Katılımcılar aldıkları ücretin ihtiyaç ve beklentilerini kısmen de olsa karşıladığını $(\bar{x}=2,80)$ ancak yoğun bir çalışma temposu (seyahatler, arazi çalışmaları, işi yetiştirmek için yapılan fazla mesailer, tatil günlerinde ofise çağırılma vb.) gerektiren bu meslekte adil bir ücrete erişemediklerini $(\bar{x}=3,30)$ ifade etmektedir. Bu bağlamda katılımcılara meslek hayatında karşılaşılan zorluklar hakkında düşünceleri sorulmuştur. Bu açık uçlu anket sorusunun yanı sıra derinlemesine görüşmelerden elde edilen bulgular bu başlıkta değerlendirilmiştir. Çalışma koşullarındaki güçlüklerin sektörlere göre farklılaştığı görülmektedir. Örneğin özel sektör çalışanları hafta sonlarında, resmî tatillerde ve gece geç saatlere kadar devam eden esnek çalışma koşullarından, fazla mesai ücreti alamamaktan, işe alınırken ve işyerinde cinsiyet ayrımcılığına maruz kalmaktan, plancı karneleri ile yeni bir ofis açsalar bile piyasada iş almalarının imkânsız olmasından (nitekim piyasada iş/ihale alımı isim yapmış birkaç şirket dışında oldukça güç olduğu belirtilmektedir) şikâyet etmektedirler. Ayrıca özel sektör çalışanlarının meslekte ilerleyememe kaygılarının yüksek olduğu görülmektedir. Özel büro sahipleri için en önemli sorun, ülkenin son yıllarda yaşadığı ekonomik durgunluk sebebiyle iş piyasalarındaki daralmadır. Diğer sorunlar ise plan onama yetkisinin birçok kurum arasında dağıtılması, yetki kargaşası, onama süreçlerinin çok uzun sürmesi, hak edişlerin resmî kurumlar tarafından zamanında ve fatura bedeli kadar ödenmemesi, sivil toplum kuruluşlarının planlara teknik olarak değil siyasi açıdan yaklaşmaları, planların yerel yönetimler tarafından siyasi araç olarak kullanılması, liyakatsiz yöneticiler, düşük bedellerle yapılan işlerdeki kalite yoksunluğu olarak sıralanmaktadır.

Kamu kurumları çalışanlarına bakıldığında ise yöneticiler tarafından yapılan imza yetkisine ilişkin baskıların (kişisel yıldırma/mobbingler) kaygı verici düzeyde olduğu görülmektedir. Ayrıca plancılar güncel bilgiye ve veriye erişim güçlügü, arşiv sorunu, bazı kanun ve mevzuatların yetersizliği, değişime ve yeniliğe direnen geleneksel bir çalışma sisteminin olması, kamuda diğer meslek gruplarının daha ön planda tutulması (plancıların ara eleman zannedilip mimar veya mühendisler kadar itibar görmemesi), mesleğin öneminin kavranmaması, herkesin kent planlama hakkında (çoğu zaman doğru olmayan) bir kanıya, fikre ve söze sahip olması sıralanan diğer sorunlardır.

İşleyiş ve kadro durumları nedeniyle kamu kurumlarından farklı bir statüye sahip (siyasi seçimle başa gelen belediye başkanı yönetimi) yerel yönetimlerde ise yine farklı kaygılar ve sorunlar gözlenmiştir. Belediye çalışanlarının öncelikli kaygıları sözleşmelerinin kişisel olmayan çeşitli nedenlerde (seçim, siyasi görüş ayrılığı, yöneticilerin değişmesi vb.) feshedilmesidir. Ayrıca diğer sorunlar; etik olmayan çalışma prensipleri, önemli boyutlara ulaşan siyasi baskılar, yöneticilerin eğitim seviyesinin ve iş ahlakının teknik bir elemana emir verecek düzeyde olmaması ve siyasetin planlara doğrudan etki 
etmesi, imar işlerinde adam kayırma, hataları görmezden gelme ve bu konuda yapılan baskılar ile merkezi ve yerel yönetimler arasındaki yetki karmaşası olarak sıralanmaktadır. Gayrimenkul ve değerleme uzmanları ise mesleki sıkıntılardan öte tam olarak kendi mesleklerini yapamamaktan şikâyetçidir. Nitekim planlama bürolarının tecrübeli eleman istemesi yeni mezunları farklı sektörlerde çalışmaya zorlamaktadır.

$\mathrm{Bu}$ başlıktaki son meslek grubu olan akademisyenlerden mesleklerinin yanı sıra planlamanın geleceğine dair bir değerlendirme yapmaları istenmiştir. Hemen her bölümde artan kontenjanların akademisyen başına düşen öğrenci sayısını ve ders yükünü artırdığı, bunun sonucunda ise araştırma ve yayın yapmanın güçleştiği, dolayısıyla nitelikli akademisyen sayısının azaldığı vurgulanmaktadır. Bu bağlamda eğitim kalitesinin özellikle yeni açılan bölümlerde (az akademisyen, çok öğrenci, kısıtlı zaman çıkmazı nedeniyle) sorgulanması gereken bir konu olduğu ifade edilmektedir. Akademisyenler diğer sorunlarını son dönemdeki gelişmeler nedeniyle (bazı akademisyenlerin medya üzerinden etik olmayan açıklamalar yapması, ücret politikalarındaki sıkıntılar, salt puan ölçütüyle mesleğe alınma vb.) toplumda saygın bir meslek grubu olarak görülmemeleri, entelektüel kalitenin düşmesi, cinsiyet ayrımcılığı nedeniyle üst düzey yöneticilik görevlerinde yer alamamak, mesleki rekabetin kişiselleştirilmesi, üniversitelerin yayın ve proje desteklerini kısıtlaması şeklinde sıralamaktadır. Planlama mesleğinin geleceğine ilişkin kaygıları ise bölüm puanlarının düşmesi, öğrencilerin kendini geliştirmek için yeterince çaba harcamaması ve mesleki etik değerlerinin dejenerasyonudur.

Profesyonellere son olarak planlama eğitiminin mesleki başarıyla ilişkisini tespit etmek üzere üç önerme yöneltilmiştir (Çizelge 5). Katılımcılar okulda edinilen teorik bilgi ve becerilerin mesleki deneyimde orta düzeyde etkili olduğunu $(\bar{x}=2,89)$ nitekim çalışma yaşamında plan çizmeye en erken 3-6 ay arasında başlanabildiğini belirtmektedirler. Katılımcıların planlamada oldukça öneme sahip bilgisayar programları kullanımı $(\bar{x}=2,43)$ ile mevzuat bilgilerinin $(\bar{x}=1,63)$ düşük düzeyde kaldığı, dolayısıyla planlama eğitimini bu noktada eleştirdikleri görülmektedir.

Çizelge 5. Planlama eğitimi ve mesleki ilişkisi

\begin{tabular}{lcc}
\hline & Ortalama $(\overline{\mathbf{x}})$ & Standart Sapma \\
\hline Planlama eğitimi süresince edindiğim teorik ve pratik bilgi ve beceriler mesleki & 2,89 & 1,17629 \\
deneyimimde yeterli oldu & 1,63 & 1,89646 \\
Mezun olduktan sonra tüm mevzuata hâkimdim & 2,43 & 1,17525 \\
Mezun olduktan sonra işim için gereken bilgisayar programlarına sahiptim & \\
\hline
\end{tabular}

\section{Sonuç ve Öneriler}

Son yirmi yılda kentleşme dinamiklerindeki değişim planlama meslek alanında değişikliğe neden olurken, Şehir ve Bölge Planlama eğitimi, şehir plancılarının meslek yaşamında karşılaşacakları zorluklarla başa çıkabilmeleri, geleneksel bilgi ve becerilerin ötesinde mesleki değişim ve gelişmelere uyum sağlayabilmeleri amacıyla yeniden formüle edilmiştir. Planlama okulları öğrencilerini sosyoekonomik ve mekânsal analiz teknikleri ile bölge ve kent sisteminin işleyişini kavrama, kentsel ve bölgesel sorunları tespit ederek geleceğe yönelik alternatif çözüm önerileri üretme gibi mesleki bilgi ve becerilerle donatmayı hedeflemektedir. Bu bağlamda öncelikle planlama eğitimine ilişkin tutumlar incelendiğinde öğrencilerin uygulamalı derslere $(\bar{x}=3,23)$, öğretim üyelerine $(\bar{x}=3,11)$ ve teorik derslere $(\bar{x}=3,06)$ orta; sınav ve değerlendirmeye $(\bar{x}=1,93)$ düşük; sosyal ilişkilere $(\bar{x}=1,19)$ ise çok düşük düzeyde puan verdiği görülmektedir. Uygulamalı derslere ilişkin genellikle pozitif bir tutum söz konusu olmasına karşın öğrenciler bu derslere ayrılan zaman ve maliyeti fazla bulmaktadır. Yapılan çalışmanın devlet üniversitelerini kapsaması ve ülkedeki ekonomik kriz nedeniyle öğrencilerin maddi imkânlarının kısıtlı olması beklenen bir durumdur. Bazı üniversitelerde palyatif bir çözüm olarak daha az sayıda, daha yakın kentlerin araştırılması öngörülse de öğrencilerin farklı ölçeklerde, farklı ekonomik, sosyal, kültürel ve mekânsal özelliklere sahip kentlerde alan araştırması yapması planlama pratiği açısından oldukça önem arz etmektedir. Bu sebeple araştırma gezilerinde ulaşım, konaklama ve yemek ücretinin üniversiteler tarafından desteklenmesi daha optimal çözüm olarak karşımıza çıkmaktadır. Ancak akademisyenlerle yapılan görüşmelerde çoğu üniversite yönetiminin yapılan alan çalışmalarını turistik bir gezi olarak algıladığı görülmektedir. Bu yanlış algının ortadan kaldıııması için tüm Planlama Bölümlerinin bir araya gelerek planlama eğitiminin ihtiyaçlarını ve gerekliliklerini üst mercilere duyurması gerekmektedir. 
Öğretim üyelerine ilişkin tutumlar incelendiğinde öğrencilere eşit mesafede yaklaşma, önyargılı değerlendirme yapma ve kişisel problemlerden soyutlanamama konuları eleştirilmektedir. Öğretim üyelerinin ülkemizde yalnızca akademik başarı kriterlerine göre (ALES, lisans not ortalaması, yabancı dil puanı vb.) mesleki hayata başlaması uzun erimde bazı sorunları beraberinde getirebilecek bir husustur. Nitekim iyi araştırma yapan ve üstün akademik başarıya sahip her bireyin ders anlatım becerilerinin ve öğrencilerle sosyal ilişkilerinin de iyi olacağı varsayılmamalıdır. Bu sebeple üniversitelerde ders veren ve araştırma yapan öğretim üyelerinin birbirinden ayrılması ve ders veren öğretim üyelerine pedagojik formasyon eğitiminin zorunlu kılınması (bazı üniversiteler öğretim üyelerinin ilk kez ya da yeniden atamalarında eğiticinin eğitimi sertifikasını bir ön koşul olarak sunmakta ve bu eğitimlerin 5 yılda bir tekrarlanmasını istemektedir) öğrencilerle iletişimi güçlendirecek ve eğitim kalitesini artıracaktır. Akademisyenlerle yapılan görüşmelerde de benzer bir tercih söz konusudur, akademisyenlerin bazıları ders anlatmaya bazıları ise araştırma yapmaya daha yatkın olduğunu açıkça ifade etmektedir. Yükseköğretim Kurulu tarafından atanma ve yükselme kriterleri bu ikircikli yapıya göre yeniden düzenlenebilir.

Tasarım ve uygulama ağırıkı planlama okullarının tümünde teorik derslerin öneminin kavranması (öğrenciler sunulan altı önermeye orta düzeyde de olsa olumlu görüş bildirmiştir) eğitim açısından önemli bir kazanımdır. Ancak teorik derslerin yüzeysel işlenmesi eleştirilmektedir ki görece daha yeni planlama okullarındaki öğretim üyelerinin ders sayıları düşünüldüğünde uzmanlık dışı birçok dersin aynı kalitede hazırlanması pek olası görünmemektedir. Yapılan görüşmelerde teorik derslere ilişkin daha farklı sorunlar da açığa çıkmıştır. Nitekim öğrenciler bazı öğretim üyelerinin derslerini sadece hazırladıkları slaytı okuyarak, kendileri ile göz teması kurmadan, herhangi bir örnek vermeden, ders katılımını umursamadan işlemesini eleştirmektedir. Meslektaşlarına ilişkin benzer durumu bazı akademisyenler de dile getirmiş, öğrencilerin bu derslerde verilen notları ezberleyerek sınavı geçtiğini, gerçek bir öğrenmenin olmadığını, bir sonraki dönem tüm bilgilerin unutulduğunu belirtmişlerdir.

Planlama eğitiminde sınav ve değerlendirmeye ilişkin tutumların diğer ölçütlere göre daha olumsuz olduğu görülmektedir. Planlama okullarında uygulamalı derslerin değerlendirmesi daha önce de belirtildiği üzere dersi veren öğretim üyelerinden oluşan bir jüri tarafından yapılmaktadır. Jüri her sınıfta hedeflenen öğrenim çıktılarına göre öğrencileri kritik etmektedir. Birden çok öğretim üyesi karşısında çalışmalarını sunmak öğrenciler üzerinde çoğu zaman psikolojik bir baskı oluştursa da profesyonel meslek hayatlarında projelerini sunmak, savunmak ve kabul ettirmek zorunda oldukları için bu işleyişin değiştirilmesi pek mümkün görünmemektedir. Ancak jürinin öğrencileri geliştirmek için yaptığı kritikler bazen kişisel algılanabilmekte ve öğrenciler tarafından sübjektif değerlendirme yapıldığı yönünde bir görüşe sebep olabilmektedir. Tüm bölümlerde benzerlik gösteren bu sorun üzerine akademisyenlerle yapılan görüşmelerde bazılarının değerlendirme kriterlerini öğrencilere açıklayarak olabildiğince şeffaf olmaya çalıştıkları gözlenmiştir. Bu durum tüm bölümlerde yaygınlaştırılabilir.

Sınav ve değerlendirme hususunda bir diğer eleştiri teorik derslerde çok fazla ödev verilmesi, ezbere dayalı bir sınav sisteminin uygulanması ve sınav soruları ile derste işlenen konuların benzerlik göstermemesidir. Akademisyenler sınavlarında ezberden uzak, yoruma dayalı bilgileri test ettiklerinde öğrencilerinin başarısız olduğunu çünkü kendilerini ifade etmekte zorlandıklarını belirtmektedir. Lisans eğitimine kadar sınava (ve ezbere) odaklı bir yaklaşıma alışkın olan öğrencilerin düşüncelerini hem sözel hem de yazılı olarak ifade etmekte zorlanması kaygı vericidir.

Planlama eğitiminin ders saatleri dışında da yoğun bir çalışmayı gerektirmesi öğrencilerin sosyal ilişki geliştirmesini ve çeşitli sosyo-kültürel aktivitelere katılımlarını hem fiziksel hem de zaman açısından zorlaştırmaktadır. Hâlbuki plancılar meslek hayatlarında katılımcı planlama anlayışıyla toplumun her kesimi ile iyi iletişim kurabilme özelliğine sahip olmalıdır. Bu durum onları yaşadıkları toplumdan bir anlamda izole etmektedir.

Planlama öğrencilerinin iş bulma ve mesleki öz yeterliliklerine ilişkin kaygı düzeylerinin ise $(\bar{x}=2,85)$ yüksek olduğu görülmektedir. Bu kaygıların başında iş bulma ve düşük ücretle istihdam edilme hususları gelmektedir ki mezun plancı sayısı ile kurumların (kamu ve ekonomik kriz nedeniyle 
küçülmeye giden özel planlama bürolarının) ihtiyaç duyduğu plancı sayısı arasında bir dengesizlik söz konusudur. Her geçen yıl bir yenisi açılan Planlama Bölümleri nedeniyle de işsiz mezun sayısında artış yaşanacağı açıktır. Kendilerinin kamu yararını gözeten, etik kurallara bağlı bir plancı olacağını ifade eden öğrenciler ne yazık ki çalışma yaşamlarında mesleki baskıya (imza ve onay baskısı) maruz kalacağını düşünmektedir. Bu kaygıların temelinde ise işe alınmalarında siyasi ve diğer referansların etkili olduğu inancı yer almaktadır. Nitekim başkaları tarafından bir yerlere getirilme mesleki ödünlerin önünü açmaktadır.

İstihdama katılan plancılara bakıldığında iş ve ücret tatmini konusunda çeşitli sorunlar belirlenmiştir. Mesleklerinin yeterince anlaşılamaması, siyasi baskılar, etik değerlerin hiçe sayılması, liyakatsiz yöneticiler en sık ifade edilen sorunlardır. Alınan ücretlerde ise plancılar ihtiyaç ve beklentilerinin kısmen de olsa karşılandığını $(\bar{x}=2,80)$ ancak yoğun ve özverili bir çalışma temposu gerektiren bu meslekte adil bir ücrete erişemediklerini $(\bar{x}=3,30)$ düşünmektedirler. Görece daha yeni plancıların ise işe ilk başladıklarında deneme süresi adı altında üç ay ila bir yıl arasında asgari ücretin altında bir maaş aldığı yapılan görüşmelerde tespit edilmiştir. TMMOB her yıl mühendis, mimar ve şehir plancılarının alması gereken minimum ücreti belirlese de planlama bürolarının bu karara pek uymadığı görülmektedir. Bu nedenle özellikle yeni mezunlar hak, görev, yetki ve sorumluluklarının bilincinde ol(a)madığı için piyasalar tarafından emek sömürüsüne maruz kalmaktadır. Bu noktada öğretim üyelerinin gelecekte öğrencilerine hak, görev, yetki ve sorumluluklarını daha iyi anlatması gerekmektedir. Mesleğe yönelik bilinçlendirme ve etkinlik çalışmalarıyla birlikte planlama öğrencilerine etik, yetki ve imza sorunları temalı özel seminer ve eğitimler düzenlenebilir.

Yeterli bilgi ve donanıma sahip meslek insanları yetiştirebilmek gelecek için en önemli eğitim yatırımlarındandır. Bu yatırımın yapılabilmesi için bölümlerindeki öğretim kadrolarının güçlendirilmesi ve öğrenci sayısının fiziksel koşullar göz önünde bulundurularak optimal düzeyde tutulması gerekmektedir. Bu kapsamda temel amaç, yeni bölümler açmak yerine mevcut Şehir ve Bölge Planlama Bölümlerinin teknolojik altyapılarının ve akademik kadrolarının geliştirilmesi olmalıdır.

\section{Kaynaklar}

Appleton-Knapp, S.L., Krentler, K.A. (2006). Measuring Student Expectations and Their Effects on Satisfaction: The Importance of Managing Student Expectations. Journal of marketing education, 28(3), 254-264.

Aşkar, P., Umay, A. (2001). Illköğretim Matematik Öğretmenliği Öğrencilerinin Bilgisayarla Illgili Öz-Yeterlilik Algısı. Hacettepe Üniversitesi Eğitim Fakültesi Dergisi, 21, 1-8.

Bandura, A. (1977). Sosyal Öğrenme Teorisi, Englewood Cliffs, NJ: Prentice-Hall.

Bandura, A. (1994). Self-efficacy, In vs. Ramachaudran. Encyclopedia of Human Behavior, 4(4), 71-81.

Blair, L. (2014). Huzur: Uyku Bozukluğu, Olumsuz Düşünce, Kaygı ve Stresle Baş Etme Yolları (C. Aral, Çev.). Ankara: Akılçelen.

Bridges, D. (1993). Transferable Skills -Philosophical Perspectives, Studies in Higher Education, 18(1), 43-52.

Brown, G. (1999). A Group Learning Approach to Academic and Transferable Skills Through an Exercise in The Global Positioning System, Journal of Geography in Higher Education, 23(3), 291-301.

Burkovik, H.Y. (2013). Kaygılanacak Ne Var!, İstanbul: Timaş.

Castells, M. (1998). The Education of City Planners in the Information Age, Berkeley Planning Journal, 12(1), 2531.

Clark, G., Wareham, T. (1998). Small Group Teaching in Geography, Cheltenham, Geography Discipline Network.

Çolakoğlu, T., Polat, E.K., Aydın, G.G. (2017). İktisadi ve Idari Bilimler Fakültesi Öğrencilerinin Isşsizlik Kaygısı Üzerine Bir Araştırma: Biga IïBF Örneği. International Journal of Innovative Approaches in Social Sciences, 1(1), 29-39.

Cüceloğlu, D. (1993). İnsan ve Davranışı. Remzi Kitabevi.

Doğan, U., Ocakçı, M. (2014). The Critical Analysis of "Design Issue" in Urban Planning Education in Accordance with the Changing Paradigms. Erciyes Üniversitesi, Sosyal Bilimler Enstitüsü Dergisi, 2(37), 111-130. 
Eysenck, H. J. (2000). The Biological Basis of Cross-Cultural Differences in Personality: Blood Group Antigens, Psychological Reports.

Gibbs, G. (1992). Improving the Quality of Student Learning, Bristol, Technical and Education Services.

Goodenow, C. (1993). Classroom Belonging Among Early Adolescent Students: Relationships to Motivation and Achievement, Journal of Early Adolescence, 13, 21-43.

Haigh M., Kilmartin, M. (1999). Student Perceptions of Development of Personal Transferable Skills, Journal of Geography in Higher Education, 23(2), 195-206.

Hall, P. (1996). Cities of Tomorrow: An Intellectual History of Urban Planning and Design in The Twentieth Century. Blackwell: Oxford.

Heumann, L., L. Wetmore. (1984). A Partial History of Planning Workshops: The Experience of Ten Schools from 1955 to 1984, Journal of Planning Education and Research 4(2), 120-130.

Higgitt, M. (1996). Addressing the New Agenda for Fieldwork in Higher Education, Journal of Geography in Higher Education, 20(3), 391-398.

Hill, F.M. (1995). Managing Service Quality in Higher Education: The Role of the Student as Primary Consumer, Quality Assurance in Education, 3(3), 10-21.

Hill, Y., Lomas, L., MacGregor, J. (2003). Students' Perceptions of Quality in Higher Education. Quality Assurance in Education, 11(1), 15-20.

Keleş, R., Yavuz, F., Geray, C. (1973). Şehircilik Sorunlar, Uygulama ve Politika, Ankara: Ankara Üniversitesi Siyasal Bilgiler Fakültesi Yayınları.

Kent, M., Gilbertson, D.D., Hunt, C.O. (1997). Fieldwork in Geography Teaching: A Critical Review of Literature and Approaches, Journal of Geography in Higher Education, 21(3), 313-332.

Kılıç H., Sevim, S. A. (2005). Ergenlerde Yalnızlık ve Bilişsel Çarpıtmalar, Ankara Üniversitesi Eğitim Bilimleri Fakültesi Dergisi, 38(2), 69-88.

Kotval, Z. (2003). Teaching Experiential Learning in the Urban Planning Curriculum, Journal of Geography in Higher Education, 27(3), 297-308.

Köroğlu, T. (2011). Şehir ve Bölge Planlama Eğitimine Eleştirel Bir Bakış: Karar Odaklı Yaklaşım, KBAM 2. Kentsel ve Bölgesel Araştırmalar Sempozyumu, 605-614, Ankara.

Lang, J. (1983). Teaching Planning to City Planning Students, An Argument for the Studio / Workshop Approach, Journal of Planning Education and Research, 2(2), 122-129.

Livingstone, D., Lynch, K. (2000). Group Project Work and Student-Centred Active Learning: Two Different Experience, Studies in Higher Education, 25(3), 325-345.

Long, J. G. (2012). State of the Studio: Revisiting the Potential of Studio Pedagogy in US-Based Planning Programs, Journal of Planning Education and Research, 32(4), 431-448.

Maier, K. (1994). Planning and an Education in Planning in the Czech Republic, Journal of planning education and research, 13(4), 263-269.

May, J. (1999). Developing Fieldwork in Social And Cultural Geography: Illustration From a Residential Field Course in Los Angeles and Las Vegas, Journal of Geography in Higher Education, 23(2), 207-226.

Minnery, J. (2000). Go, And Do Thou Likewise? Planning Practice in Planning Education, Australian Planner, 37(1), 39-46.

Millar, E., Walsh, M. (2000). Mental Health Matters in Primary Care, Stanley Thornes (Publishers), United Kingdom.

Osterman, K. F. (2000). Students' Need for Belonging in the School Community, Review of Educational Research, 70, 323-367.

Pozo-Munoz, C., Rebolloso-Pacheco, E., Fernandez-Ramirez, B. (2000). The "Ideal Teacher". Implications for Student Evaluation of Teacher Effectiveness, Assessment and Evaluation in Higher Education, 25(3), 25363. 
Roakes, S.L., Norris-Tirrell, D. (2000). Community Service Learning in Planning Education: A Framework for Course Development, Journal of Planning Education and Research, 20(1), 100-110.

Roeser, R.W., Midgley, C., Urdan, T.C. (1996). Perceptions of The School Psychological Environment and Early Adolescents' Psychological and Behavioral Functioning in School: The Mediating Role of Goals and Belonging, Journal of Educational Psychology, 88, 408-422.

Semerci, Ç. (2007). Eğitimde Ölçme ve Değerlendirme, Ölçme ve Değerlendirme İçinde (ss.1-15). Ankara: PegemA Yayınları.

Tallis, F., Eysenck, M., Mathews, A. (1992). A Questionnaire for the Measurement of Nonpathological Worry, Personality and individual differences,13(2), 161-168.

Taşğın, Ö., Tekin, M., Altınok, E. (2007). Beden Eğitimi Öğretmenlerinin Çeşitli Değişkenler Açısından Kaygı Düzeylerinin İncelenmesi (Batman İl Örneği), Beden Eğitimi ve Spor Bilimleri Dergisi, 9(4), 12-20.

Taylor, E.A. (1999). How Does Peer Support Relate to African-American Adolescents' Academic Outcomes? Testing a Conceptual Model, Paper presented at the Biennial Meeting of the Society for Research in Child Development, Albuquerque, NM.

TUPOB, (2007). Türkiye'de Şehir ve Bölge Planlama Eğitiminde Kalite Geliştirme ve Akreditasyon, İstanbul: Türkiye Planlama Okulları Birliği III. Dönem Çalışmaları.

Voss, R., Gruber, T., Szmigin, I. (2007). Service Quality in Higher Education: The Role of Student Expectations, Journal of Business Research, 60(9), 949-959.

Yabes, R. (1996). Cooperative Learning in Planning Education, Paper presented at the ACSP-AESOP Joint International Congress, Toronto, Canada.

Yenilmez, K., Özbey, N. (2006). Özel Okul ve Devlet Okulu Öğrencilerinin Matematik Kaygı Düzeyleri Üzerine Bir Araştırma, Uludağ Üniversitesi Eğitim Fakültesi Dergisi, 19(2), 431-448

Yeşilyurt, F. (2007). ÖSS ve OKS'de Sınav Kaygısı ve Baş Etme Yolları, İstanbul: Remzi Kitapevi.

URL-1, Ortadoğu Teknik Üniversitesi Şehir ve Bölge Planlama Bölüm Tanıtımı, Erişim Tarihi: 09.08.2018, http://crp.metu.edu.tr/sites/crp.metu.edu.tr/files/SBP_2013m4_SON.pdf

URL-2. YÖK İstatistiği, Erişim Tarihi: 11.08.2018, https://istatistik.yok.gov.tr

URL-3. Türk Dil Kurumu, Erişim Tarihi: 10.07.2018, http://sozluk.gov.tr 